\title{
A STUDY ON ERRORS IN PRONOUNCING DENTAL SOUNDS OF ENGLISH-MAJORED SOPHOMORES AT TAY DO UNIVERSITY, VIETNAM
}

\author{
Thi Truc Ly Bui ${ }^{i}$, \\ Thanh Hiep Mai, \\ Thao Nguyen Nguyen \\ Tay Do University, \\ Vietnam
}

\begin{abstract}
:
It is not deniable that pronunciation is considered one of the most crucial parts of learning English helping learners enhance their communication in both speaking and listening comprehension. To reach a level of a clear and precise pronunciation has never been an effortless task; however, it is a far more problematic one for English majored students regardless of their learning years. For this reason, the study entitled "Common Errors in Pronouncing Dental Sounds of English-Majored Sophomores at Tay Do University" was implemented with the aim at investigating the errors that English-majored students encountered in pronouncing dental sounds. 80 English-majored sophomores from course 14 at Tay Do University were selected to participate in the study. Questionnaires and recording tests were delivered to the participants for collecting data and getting more information. The collected data from the two instruments mentioned above was all analyzed afterward. The findings of the research revealed that sophomores of English major often mispronounced the dental sounds, including omission and substitution. The results of this study may also be useful for those who are interested in this field.
\end{abstract}

Keywords: errors, pronouncing dental sounds

\section{Chapter 1: Introduction}

This chapter mentions (1) the rationale, (2) the significance of the study and (3) the organization of the study.

\subsection{Rationale}

English is a common language in the world, has been widely used in many nations and territories. Most people use English to study and communicate in many fields such as

iCorrespondence: email bttly@tdu.edu.vn 
economy, culture, society, etc. Nowadays, the society is developing more and more, the need of learning English in Vietnam has been increasing day by day. People learn English to get better job, study abroad or to fulfill their personal needs. For these reasons, English is very important to everyone who wants to integrate into the world.

Moreover, conquering English is not easy for many students, especially students studying at Tay Do University. They have difficulties in learning English at school. Pronunciation is one of the difficult problems for students. This difficulty stems from the fact that students do not focus on pronunciation at the high school and junior high school, but instead, focus on learning grammar or vocabulary. Another objective reason, Nguyen (2007) researched the differences in Vietnamese and English final consonants, which led to the difficulties of Vietnamese in pronouncing English final consonants. According to AMP Fact sheets of AMP Research Centre, "learners with good pronunciation in English are more likely to be understood even if they make errors in other areas, whereas learners whose pronunciation is difficult to understand will not be understood, even if their grammar is perfect".

Therefore, the students found that their pronunciation was misleading as well as the listeners did not understand the content in university environment. Especially, English majored-sophomores at Tay Do University often make mistakes in dental sounds $[\mathrm{f}, \mathrm{v}, \theta, \mathrm{\partial}]$. However, there has not been many researchers done on this topic.

For the above reasons, the research "A study on errors in pronouncing dental sounds of English-majored sophomores at Tay Do University" was conducted to explore these issues deeply and find ways to solve difficulties so that students can improve their pronunciation skills.

\subsection{The significance of the study}

After learning about the errors of pronouncing dental sounds encountered by English majored sophomores at Tay Do University, the findings of the research can help students identify the problems they are facing promptly to find the right learning method. As a result, students can improve their pronunciation skills as well as become more confident in communication.

In addition, this research paper was hoped to provide useful information to assist teachers in recognizing the errors of students and having an effective teaching strategy. Since then, teachers have quality lectures and students gain efficiency in their learning.

\subsection{The organization of the study}

The research is made up of five main chapters as follows:

Chapter 1, Introduction, gives the rationale, significance and organization of the study.

Chapter 2, Literature Review, provides the theoretical background of pronunciation, consisting of the concepts of pronunciation, the importance of pronunciation, errors in pronouncing dental sounds and the previous studies.

Chapter 3, Research Methodology, indicates the study's method employed in this thesis including such features as research design, participants, instruments and 
procedures. Beside, research aims, research questions and hypothesis are also listed in this chapter.

Chapter 4, Results and Discussion, reports the findings of the research to figure out the participants' common errors in pronouncing dental sounds. Then, the discussion will follow to wrap up this chapter.

Chapter 5, Conclusions, Implications, Limitations and Recommendations.

\section{Chapter 2: Literature Review}

This chapter describes in details (1) the definitions of pronunciation, (2) the importance of pronunciation, (3) the definitions of dental sounds, (4) the types of dental sounds, (5) the errors in pronouncing dental sounds and influencing factors and (6) previous studies.

\subsection{Definitions of pronunciation}

Pronunciation is one of the important keys to success in speaking English or any other language. With good pronunciation skills, people can easily convey messages that the receiver can understand and fully mean. There have been a number of definitions of pronunciation by different linguists and researchers.

First of all, according to Wikipedia "Pronunciation is the way in which a word or a language is spoken. This may refer to generally agreed-upon sequences of sounds used in speaking a given word or language in a specific dialect (correct pronunciation) or simply the way a particular individual speaks a word or language." The Cambridge Advance Learner's Dictionary (2008) also stated that pronunciation refers to the way in which a language or a particular sound is pronounced or how a word or sound is produced. Carter and Nunan (2001) also have the statement about the definitions of pronunciation. Pronunciation means the production and perception of the significant sounds serving for accomplishing meaning in language use.

Similarly, Cook (1996 as cited in Pourhosein Gilakjani, 2016) defined pronunciation as the production of English sounds. Pronunciation is learnt by repeating sounds and correcting them when produced inaccurately. When learners start learning pronunciation, they make new habits and overcome the difficulties resulting from the first language. According to Yates (2002 as cited in Pourhosein Gilakjani, 2016), pronunciation is the production of sounds that is used for making meaning. Pronunciation refers to the production of sounds that we use to make meaning. It includes attention to the particular sounds of a language (segments), aspects of speech beyond the level of the individual sound, such as intonation, phrasing, stress, timing, rhythm (supra-segmental aspects), how the voice is projected (voice quality) and, in its broadest definition, attention to gestures and expressions that are closely related to the way we speak a language. Besides, pronunciation is the production of a sound system which does not interfere with communication either from the speakers' or the listeners' viewpoint (Paulston \& Burder, 1976). Pronunciation is the way of uttering a word in an 
accepted manner (Otlowski, 1998). Richard and Schmidt (2002) defined pronunciation as the method of producing certain sounds.

Furthermore, pronunciation has been described as the "Cinderella" of language teaching (CelceMurcia, Brinton \& Goodwin, 1996; Seidlhofer, 2001). Chavangklang (2013) also agreed that pronunciation is awarded as one of the main subjects of L2 (second language), students are still difficult to deal with English pronunciation although they have studied English for many years. According to James (2010), acceptable pronunciation can be understood based on the following basic levels. In level 1, what the speaker is saying is not understandable to people. In level 2, what the speaker is saying can be understandable to people, but the speaker's pronunciation is not acceptable to listen to because he/she has a strange and heavy accent. In level 3, people understand the speaker and the speaker's English is acceptable to listen to.

In addition to many studies, Ngoc Han (2018) defined that pronunciation is a method of producing sounds so that the speaker can express ideas and feelings with other people. The studies of Macdonald, Yule, and Powers (1994) and Dewing, Munro, and Wiebe (1997) suggested that pronunciation is an essential part of a language and influences language expression.

All in all, the definitions above show that pronunciation is an indispensable factor in communication. Definitions help learners with clarity and provide optimal solutions to improve their English proficiency effectively.

\subsection{The importance of pronunciation}

There are many people learning English with the aim of communicating with foreigners or native speakers. In order to communicate well, the first point they need to concern about is pronunciation. Therefore, pronunciation is one of the most important things that learners have to master in order to communicate appropriately and fluently. According to Suwartono (2006: 41), pronunciation is an essential part of a language, for the nature of language is spoken. Pronunciation is the most important and difficult problem that non-native English speakers have to face when studying English. A common mistake made by many international students who study English as a foreign language is not paying attention to English pronunciation well. Most of students underestimate the importance of pronunciation because they consider that the pronunciation is less important than other English aspects such as grammar, lexicology and vocabulary.

Pronunciation is a key factor for learners to communicate well. Thus, good pronunciation skills and communication ability are closely linked. A study carried out by Rajadurai (2001) on the attitude and concern for accurate English pronunciation among a group of Malaysian ESL teacher trainees showed that more than $80 \%$ of the trainees agreed that pronunciation is an important element in English communication.

Besides, pronunciation is also important for listening comprehension skills in English. Standard pronunciation that is, learners know how words are pronounced. Therefore, it is very helpful for listening comprehension. According to Anil (2008) "pronunciation reinforces listening you've recently learnt through repeated exposure. Specifically, 
hearing someone say the word the first time after you learnt its pronunciation can be very reassuring".

In short, no one can deny that pronunciation is very important in learning to communicate. Because, the first step of communication is to pronounce correctly, which helps listeners to correctly understand the message being conveyed. Moreover, learners want to communicate like a native speaker, then pronunciation is an aspect that must be mastered. From the above points of view, the research will show that correct pronunciation brings many benefits and consequences of mispronouncing.

\subsubsection{The advantages of having good pronunciation}

Good pronunciation has many advantages in personal and social life. It gives advantages when applying for jobs, Seidlhofer (2001) said that for university graduates, clear pronunciation during job interviews, proposal presentations, negotiations and other professional instructions is vital to ensure their successful transition into the professional realm. Shak (2016) also said that to university graduates, obviously pronunciation is an important thing to make sure of their success in finding a job during interviews. Employers will have a bad impression and right away refuse to accept their employment applications unless they make a good impression on the employers by showing their professional language. Furthermore, right pronunciation can help with the process of acquiring new vocabulary. Pronouncing words is often a part of memorizing vocabulary in second-language learning, so getting a strong, basic foundation in correct pronunciation early on will equate to more effective learning overall. According to AMP Fact sheets of AMP Research Centre, "learners with good pronunciation in English are more likely to be understood even if they make errors in other areas, whereas learners whose pronunciation is difficult to understand will not be understood, even if their grammar is perfect". Besides, having good pronunciation is the foundation for improving speaking skills. According to Omniglot Education page "If you speak a foreign language with a strong foreign accent, people may have difficulty understanding you, even if you use the grammar of the language well and have an extensive knowledge of the vocabulary. The better your pronunciation, the easier it will be for others to understand you and for you to understand them." In listening comprehension, good pronunciation listening skills will be improved. Although perfect listening is dependent on many aspects, such as vocabulary, grammar, fluency, etc. However, good pronunciation will help learners become familiar with the sounds and rhythms of the language. In summary, learners will understand most of what they hear. Thus, good pronunciation has supported learners to develop more in many other skills and fields.

\subsubsection{The consequences of mispronunciation}

To speak a second language besides their mother tongue well, pronunciation is a difficult skill for many learners. Mispronouncing is an error that many people make for number of reasons such as reading difficulties, nonstandard spelling, local or regional mispronunciations and hearing problems. According to Kristin Lems, Leah D. Miller, and 
Tenena M. Soro,( 2010) "ELLS may mispronounce a word because some of the sounds do not exist in their first language and they have not learned to say them in English, or because the letters they are trying to pronounce map to different sounds in their native language". These causes make learners' pronunciation small or completely wrong in comparison to the standard of language original language.

First of all, if the pronunciation is not correct, the listener will not understand what is being transmitted because in native communication or English speakers are often more concerned with pronunciation than with grammar or vocabulary. According to AMP Fact sheets of AMP Research Centre, "learners with good pronunciation in English are more likely to be understood even if they make errors in other areas, whereas learners whose pronunciation is difficult to understand will not be understood, even if their grammar is perfect".

Secondly, improper pronunciation also affects listening comprehension skill. In listening comprehension, the listener can only rely on the speaker's pronunciation. Therefore, when mispronouncing, it means that the listener cannot understand the listening content. O'Neal (2015) said that if the speakers pronounce a word or express their feelings, and the listeners cannot realize the pronunciation, then the pronunciation is impossible to understand to the listeners.

Finally, English is a language with a variety of words and meanings. In English, a word can have many different meanings. To distinguish these diverse meanings, native speakers or English speakers rely mainly on pronunciation. That is also the reason why the speakers have knowledge of grammar and vocabulary, but when speaking, native speakers often do not understand or misunderstand the idea.

To sum up, the consequences of mispronouncing are very serious. It will affect other skills as well as the process of learning English in the future. For this reason, learners need to focus on pronunciation instead of just learning grammar and vocabulary.

\subsection{Definitions of dental sounds}

The dental consonant or dental sound is a consonant sound used in some spoken languages, which is familiar to English-speakers. In linguistics, a dental consonant is a consonant articulated with the tongue against the upper teeth, such as $/ \mathrm{t} /, / \mathrm{d} /, / \mathrm{n} /$, and /1/ in some languages. Dentals are primarily distinguished from sounds in which contact is made with the tongue and the gum ridge, as in English (see Alveolar consonant), due to the acoustic similarity of the sounds and the fact that in the Roman alphabet they are generally written using the same symbols $(t, d, n$, and so on).

Dental sounds involve the tongue tip (active articulator) making contact with the upper teeth to form a place of articulation. Its place of articulation is dental, which means it is articulated with either the tip or the blade of the tongue at the upper teeth, termed respectively apical and labial. Almost all stops and liquids are described as dental.

In addition, if the air stream meets an incomplete obstruction somewhere in the mouth because an articulator has moved close to its point of articulation, thus causing friction, dental sound is also known as a fricative sound. They are also called constrictive 
sounds because the air is constricted and escapes through the narrowing. There are eight fricative sounds in English including [f, v, s, z, $\theta$, $\left., \int, 3\right]$.

In short, it can be seen that dental consonants are difficult to pronounce in English. Dental consonants are made up of the lips, tongue and key parts of the dental. There are 2 types of dental sound formed based on the places of articulation are labio-dental and inter-dental. These are described in the table below along with 20 other consonants.

Table 1: Chart of English consonants phonemes (Roach, 2009)

\begin{tabular}{|c|c|c|c|c|c|c|c|c|c|c|}
\hline \multirow[b]{2}{*}{$\begin{array}{l}\text { Manners of } \\
\text { articulation }\end{array}$} & \multicolumn{9}{|c|}{ Places of articulation } & \multirow[b]{2}{*}{$\begin{array}{l}\text { Work of } \\
\text { vocal cords }\end{array}$} \\
\hline & $\begin{array}{c}\text { Bi- } \\
\text { labial }\end{array}$ & $\begin{array}{c}\text { Labio } \\
- \\
\text { dental }\end{array}$ & $\begin{array}{l}\text { Inter- } \\
\text { dental }\end{array}$ & $\begin{array}{l}\text { Apico- } \\
\text { alveolar }\end{array}$ & $\begin{array}{l}\text { Post- } \\
\text { alveolar }\end{array}$ & $\begin{array}{c}\text { Alve- } \\
\text { palatal }\end{array}$ & $\begin{array}{l}\text { Fronto- } \\
\text { palatal }\end{array}$ & $\begin{array}{l}\text { Dorso } \\
\text {-velar }\end{array}$ & Glottal & \\
\hline Plosive & $\begin{array}{l}\mathrm{p} \\
\mathrm{b}\end{array}$ & & & $\begin{array}{l}\mathrm{t} \\
\mathrm{d}\end{array}$ & & & & $\begin{array}{l}\mathrm{k} \\
\mathrm{g}\end{array}$ & & $\begin{array}{c}\text { voiceless } \\
\text { voiced }\end{array}$ \\
\hline Nasal & m & & & $\mathrm{n}$ & & & & y & & voiced \\
\hline Fricative & & $\begin{array}{l}\mathrm{f} \\
\mathrm{v}\end{array}$ & $\begin{array}{l}\theta \\
\partial\end{array}$ & $\begin{array}{l}\mathrm{s} \\
\mathrm{z}\end{array}$ & & $\int_{3}$ & & & & $\begin{array}{c}\text { voiceless } \\
\text { voiced }\end{array}$ \\
\hline Liquid & & & & 1 & & & & & & voiced \\
\hline Affricate & & & & & & $\begin{array}{l}\mathrm{t} \int \\
\mathrm{d} 3\end{array}$ & & & & $\begin{array}{c}\text { voiceless } \\
\text { voiced }\end{array}$ \\
\hline Glides & & & & & $\mathbf{r}$ & & j & w & $\mathbf{h}$ & $\begin{array}{l}\text { voiceless } \\
\text { voiced }\end{array}$ \\
\hline
\end{tabular}

\subsection{Types of dental sounds}

With each different position, the sound emitted will be different and create the unique characteristics of the two types of dental sounds. Based on the place of articulation, English dental consonant sounds are divided into 2 categories: labio-dental, inter-dental (Qui, H.N, 2010).

\section{a. Labio-dental}

Labio-dental [f, v] are labio-dental fricatives; [f] is strong and voiceless; [v] is weak and voiced, and in the final position, it is partly devoiced.

Figure 1: Labio-dental sounds

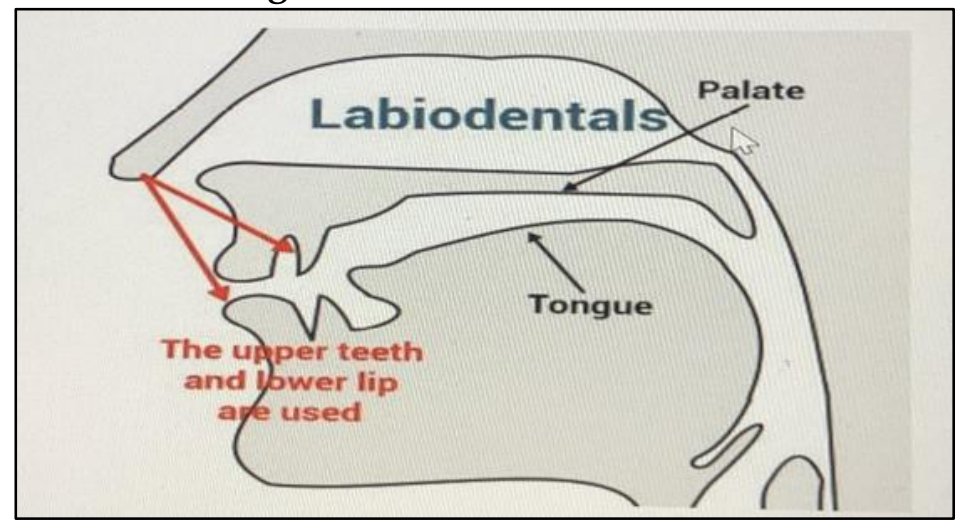


Labio-dental is created thanks to two main parts: lips and teeth. The lower lip is very close to the edge of the upper front teeth, thus forming an incomplete obstruction. When the air goes through the narrowing, it causes slight friction.

- The English [f] sound is known as a voiceless labiodental fricative consonant. This consonant is articulated by the lower lip against the upper teeth. This consonant is produced by forming a narrow air passage between the two articulators; the air is released out through the mouth and produces a hissing sound. The vocal cords are not made to vibrate during the production of this sound. This consonant in English is regarded as the representation of graphemes $\mathrm{f}, \mathrm{ff}$, gh and $\mathrm{ph}$.

- The English [v] sound is defined as a voiced labiodental fricative consonant. This consonant is articulated by the lower lip against the upper teeth. This consonant is produced by forming a narrow air passage between the two articulators; the air is released out through the mouth and produces a hissing sound. The vocal cords are not made to vibrate during the production of this sound. This consonant in English is regarded as the representation of graphemes $\mathrm{v}$ and $\mathrm{ph}$.

\section{b. Inter-dental}

Inter-dental $[\theta, \chi]$ are inter-dental fricative consonants. [ $\theta]$ is strong and voiceless; [ð] is weak and voiced, in the final position it is partly devoiced. $[\theta$, $]$ occur in word initial, word medial and word final position.

Figure 2: (Inter) dental sounds

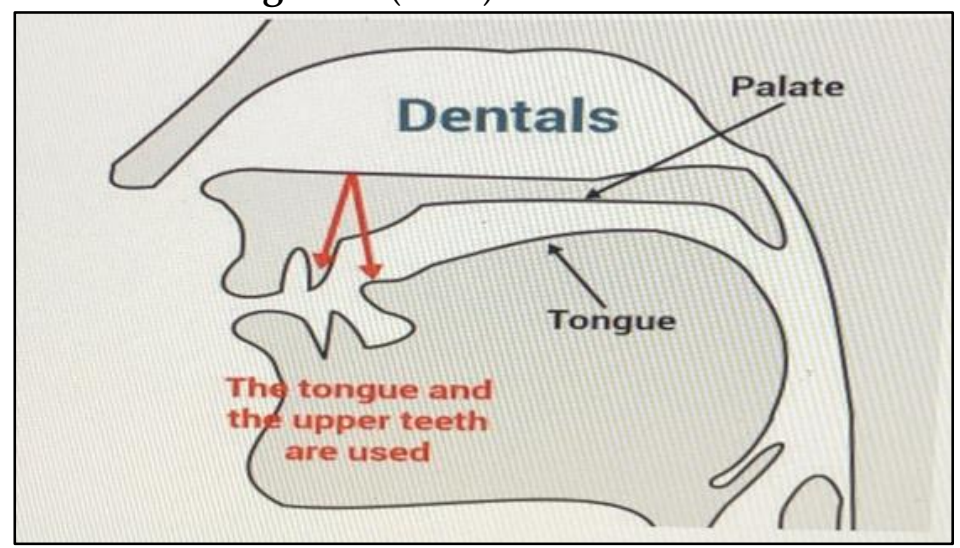

Similar to labio-dental, inter-dental is created thanks to two main parts: tongue and teeth. The tip of the tongue is either close to the edge of the upper teeth or slightly projected between the teeth.

- For [ð] sound, it articulates the back of the upper teeth with the tip of the tongue. This consonant is produced by breathing out, while moving the tongue sharply downward, and letting airflow past the tongue and out of the mouth. The vocal cords will vibrate.

- For $[\theta]$ sound, in the same way that $[ð]$, the $[\theta]$ sound is articulated from the back of the upper teeth with the tip of the tongue. This consonant is produced by breathing out, 
while moving the tongue sharply downward, and letting airflow past the tongue and out of the mouth. However, the vocal cords will not vibrate.

\subsection{The common errors of pronouncing dental sounds and influencing factors}

\subsubsection{Errors with labio-dental sounds /f/ and /v/}

In linguistics, /f/ is a voiceless labio-dental fricative consonant. /v/ is voiced labio-dental fricative consonant. The / $\mathrm{f} /$ and / $\mathrm{v} /$ sounds have similar pronunciation mechanisms. Therefore, the sound output is almost the same. /f/ and / $/$ can be distinguished through the following: /f/ is a voiceless sound, /v/ is a voiced sound. Because they are too similar, it leads to confusion among learners. They usually pronounce /f/ and /v/ the same.

Figure 3: The way /f/ and /v/ are made

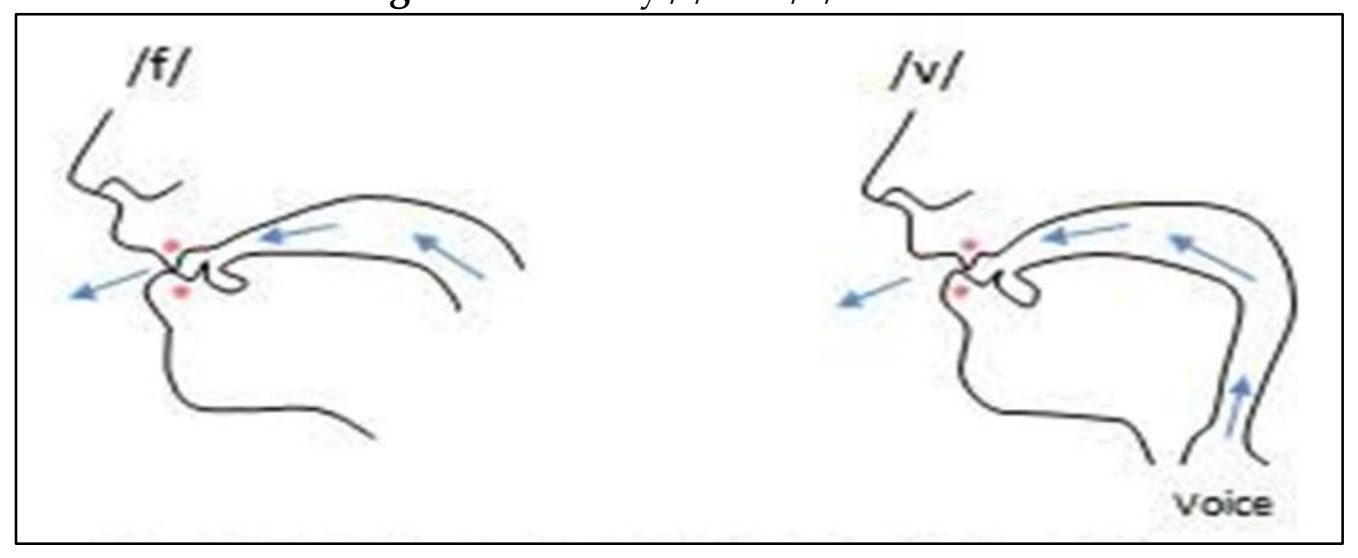

In addition, there is no final consonant in Vietnamese language. Conversely, native speakers or English speakers depend on the final consonant to be able to communicate. In English, / v / and / f / are often at the end of words. Therefore, learners often make mistakes by not pronouncing the ending sounds / f / and / v /.

\subsubsection{Errors with inter-dental sounds $/ \boldsymbol{\theta} /$ and / $/ \mathbf{~}$}

The English $/ \theta /$ and $/ ð /$ are inter-dental fricative consonants. They are considered two difficult consonants for Vietnamese learners to study English. Honey (1987) said that the Vietnamese consonant system is very different from that of the English, and there is considerable variation between dialects. Vietnamese learners of English can be expected to come across particular difficulty with some or all of the following sounds: /f/, / $/$ /, /ð/, /z/.

In another research paper, (Avery and Ehrlich, 1992, p. 155) also showed that "Vietnamese speakers often create a heavily voiceless stop / $/$ / instead of a voiceless fricative $/ \theta /$ in a word like thank. Apparently, they vocalize the sound /t/ based on their language since in Vietnamese the letter 'th' is combined by a heavily aspirated / $t$. So, the word three can be pronounced exactly like tree. Vietnamese learners of English commonly produce /d/ or /z/ for /ठ/ sounds, so the word than may sound like/dæn/ or /zæn/." Besides, in consonant blends, they 
have problems with "th" sound because they are not accustomed to putting " $\mathrm{t}$ " and " $\mathrm{h}$ " together to form "th" sound to reproduce (Dung, 2014).

Figure 4: The way $/ \theta /$ and $/ ð /$ are made

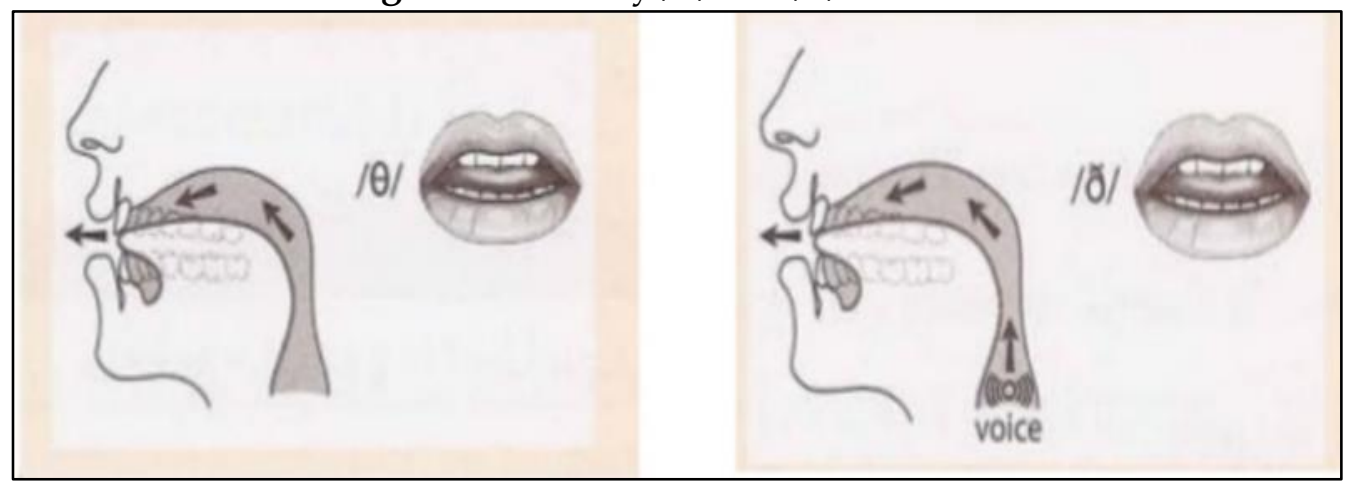

In addition, Vietnamese people have a natural reaction to the /ð/ sound because it is similar to /th/ in Vietnamese and some words are pronounced similar to Vietnamese , for example ' thanks' like ' thanh', ect. Obviously, the evidence has shown that the Vietnamese are using the Vietnam alternative to speak English. Sound substitution has been the most dominant tendency in Vietnamese students' pronunciation of $/ ð /$ and / $\theta /$.

\subsubsection{The causes of dental sounds pronunciation errors}

There have been many causes of faulty pronunciation. Some common causes are the influence of mother language, psychological factors, learning environment and the organization of pronunciation parts.

First of all, learners are deeply influenced by their mother language. Learners still use the habit of speaking Vietnamese to speak English. According to Akudela Tom (2000) "mother tongue interferes in those areas that some of the English vowels and consonants are not contained in the language of a bilingual, he says that it has developed a blind spot for those English phonemes that do not exist in mother language interference". They often find it difficult to speak English, especially the tones because there is no interference between English and their native language. For Hilfert (2000) she explained that "any speaker who speaks English as a second language (L2) is likely to have difficulty in speaking like the native speaker of English (L1)". This of course is due to the fact that it is not their first language, and as their second language, they were imperfect speakers of the language.

Secondly, psychological factors also significantly affect the learners' mispronouncing of dental sounds. Learners are not interested in pronunciation learning they focus on learning vocabulary and grammar. According to AMP Fact sheets of AMP Research Centre, "learners with good pronunciation in English are more likely to be understood even if they make errors in other areas, whereas learners whose pronunciation is difficult to understand will not be understood, even if their grammar is perfect". Bill page said, "Self-esteem in communication is also a difficulty when learning to communicate in English. Psychology is a big barrier that directly affects the process of improving English communication". From mispronouncing the sounds, learners are not confident in pronouncing the sounds. 
Thirdly, the learning environment also affects their pronunciation skills. At school, practice time is not enough for learners. Above all, they mainly practice with teachers or friends (who are also Vietnamese) do not have many opportunities to practice with native speakers. In addition, the current pronunciation study program is not really suitable for the students.

Finally, in order to create the correct sound, learners must use many articulating parts, so when the speaker combines these sound parts, they accidentally make the sound go wrong. As Mtrend page said "the fine coordination between the breath and the vocal control muscles will determine whether the sound is appropriate or not". That is also one of the reasons why learners pronounce the wrong sounds.

In general, there are objective reasons as well as subjective reasons why learners have trouble with dental sound. To improve the mistakes they are making, learners are looking for ways to solve and practice positively.

\subsection{The previous studies}

Many studies have been conducted to find out the problems in the pronunciation of English language which were made by students. All over the world, linguists and researchers have demonstrated that the errors made by the speakers of English language are systematic rather than random.

According to Moosa (1972) and Homedan (1984), Arab students who speak English with problems in the pronunciation of sounds, which are not familiar. Therefore, they substitute the sounds that they do not have in their native language, with other sounds, which are close to them in the place of articulation. For instance, they replace $/ \theta /$ with /th/, /ð/ with /d/.

Similarly, several studies conducted by Vietnamese researchers showed that Vietnamese learners encounter many difficulties in learning English pronunciation and also make common errors of mispronunciation. Dung (2014) pointed out that Vietnamese speakers have a wider number of problems with the voiced versus the voiceless stops in final fricative consonants $/ \mathrm{f} /, / \mathrm{v} /, / \theta /, / ð /$. In addition to the past works, Duong Thi Nu (2009, p. 41-50) has studied pronunciation problems and the influence of the mother tongue. She highlighted that the common pronunciation mistakes of Vietnamese learners are confusion in terms of consonant sounds. So many sounds such as /f/ and /v/, /ð/ and $/ \theta /, / d z /$ and / $3 /$.

Another the result of the study indicated by $\mathrm{Nu}$ was the effect of the sound system on learning pronunciation. She showed that the main problem in teaching and learning English pronunciation results from the differences in the sound system of English and the system of Vietnamese, so a Vietnamese student is not accustomed to pronouncing for instance $\theta$-sound and $\partial$-sound, because they do not find in his native language. This means that the organs of speech of the learner are not trained to produce such sound systems because they are unfamiliar to students. Particularly, the differences between the two languages are the differences in manner of articulation, place of articulation, and voicing in Vietnamese and English. 
Despite a variety of topics related to pronunciation, not many researchers pay attention to the common errors with dental consonants of Vietnamese English majored sophomores. Although they are students of English linguistics, surely, they have not concentrated on pronunciation, especially the dental sounds.

\section{Chapter 3: Research Methodology}

This chapter shows in detail (1) Research aims (2) Research question. Besides, It also refers to (3) Research design (4) Participants (5) Instruments and (6) Procedures

\subsection{Research aims}

The aim of this study was to find out some common errors in pronouncing dental sounds $/ \theta /, / ð /, / f /$ and /v/ of English-majored sophomores at Tay Do University and the study also showed the causes of these errors so that the students could avoid making mistakes as well as find ways to improve their pronunciation.

\subsection{Research questions}

This study was undertaken with the purpose of dealing with the three following research questions:

1) Do the English-majored sophomores at Tay Do University encounter errors in pronouncing dental sounds?

2) What are English-majored sophomores' errors in pronouncing the dental sounds $/ \theta /, / ð /, / f /$ and $/ \mathrm{v} /$ ?

3) What are causes of English-majored sophomores' errors when they pronounce the dental sounds?

\subsection{Research design}

The study used quantitative and qualitative research to find out the errors in pronouncing dental sounds of English majored sophomores at Tay Do University. The reliability and validity of the research results were based on the instruments. Questionnaire and recording test were used to collect data from the participants. The collected information of these two instruments was employed to investigate common errors in dental sounds of English-majored sophomores at Tay Do University as well as their reasons of these errors.

\subsection{Participants}

The participants of this study were 80 sophomores from the English majored course 14 at Tay Do University. In fact, they were selected randomly, including both males and females. Their English level was the immediate and they studied in the different classes. There were 25 students who came from English 14A, 30 students came from in English $14 \mathrm{~B}$ and 25 students came from in English 14C. Most of them were over the age of 20 and others were from 21 years old to 22 years old. They speak Vietnamese as their mother 
tongue and English is considered their foreign language. In addition, they have learnt English for at least 7 years (4 years in secondary school and 3 years in high school). In particular, all students have completed three modules in pronunciation at Tay Do University. Questionnaire and recording test were implemented in order to get information about errors students usually face in pronouncing dental sounds.

\subsection{Instruments}

To answer the research question in the present study, the researchers measured the participants' errors in pronouncing dental sounds of English-majored sophomores. The instruments used in this research were the questionnaire and recording test.

\subsubsection{Questionnaire}

The questionnaire was designed based on theory and previous studies of pronouncing dental sound errors. The purpose of using the questionnaire was to find the causes of the mistakes as well as the pronunciation errors that English speakers were making. Eighty participants took the questionnaire with the guidance of the researcher. The questionnaire comprised 27 questions in total (see appendix A) and was divided into two parts described as follows.

Part 1 consisted of the first 7 questions (numbered from 1 to 7 ) which investigated the students' background and their opinions related to pronunciation. In this part, students were required to choose the answer that best suited their opinion. In some cases, they would give their specific answers (question 1) and choose more than one answer (question 2, question 6 and question 7). In the questions 3, 4 and 5 students will choose based on their individual thinking and judgment.

In part 2, there were 20 statements (numbered from 1 to 20) designed in form of the five-degree Likert-type scale (strongly agree, agree, neutral, disagree and strongly disagree). Students could tick in the appropriate column next to each statement provided. Statements 1 and 2 aimed to investigate students' perspectives on the importance of pronunciation. Statements 3 and 4 aimed to investigate the influence of the mother language on the pronunciation of dental sounds. Statements 5 and 6 investigated psychological factors of students. Statement 7 to 9 surveyed about the learning environment. Statement 10 to 18 raised typical problems as well as students' mistakes in the pronouncing dental sounds $(/ \theta /, / ð /, / f /$ and /v/). The last two statements were intended to learn more about how students use the parts of their verbal gestures (lip, tongue, teeth). All the information was collected and then analyzed qualitatively and quantitatively. To easily learn about the questionnaire, the research conducted the following table: 
Thi Truc Ly Bui, Thanh Hiep Mai, Thao Nguyen Nguyen

A STUDY ON ERRORS IN PRONOUNCING DENTAL SOUNDS OF

ENGLISH-MAJORED SOPHOMORES AT TAY DO UNIVERSITY, VIETNAM

\begin{tabular}{|l|l|}
\hline \multicolumn{1}{|c|}{ Statements } & \multicolumn{1}{c|}{ Summary of the statement } \\
\hline Part 1: Statement 1 to 7 & Students' background and their opinions \\
\hline Part 2: Statement 1 and 2 & Importance of pronunciation \\
\hline Statement 3 and 4 & Influence of mother language \\
\hline Statement 5 and 6 & Psychological factors \\
\hline Statement 7 to 9 & Study environment \\
\hline Statement 10 to 18 & Problems and errors \\
\hline Statement 19 and 20 & Parts of the verbal gestures \\
\hline
\end{tabular}

\subsubsection{Recording}

To evaluate the learners' ability to pronounce dental sounds, the researchers conducted a recording test. The recording was divided into two parts. At the beginning of each part, the researcher gave the five pairs of dental sounds for the participants to pronounce. The positions of five pairs were arranged as follows: the beginning position for first two pairs of sounds, the middle position for third pair and the ending position for the other two pairs. Researchers arranged the pairs of sounds in a specific sequence so that students could more easily recognize which positions they are making mistakes. In addition, the arrangement of the sound pairs also showed that even though they were specifically suggested by the researcher, the students still made mistakes in pronunciation. The remainder of the recording test were three single sentences with the positions of the dental sounds randomly assigned by the researcher. Dental sounds-containing single sentences were given on a recording test to compare the student's word pronunciation (with clues) and sentence pronunciation (without clues). In addition, the researcher also had additional evidence of the students' pronouncing dental sound errors. The words containing the dental sounds $(/ \theta /, / ð /, / f /$ and $/ \mathrm{v} /)$ consonants were set in those sentences as nouns, adjectives or verbs. The fifteen students participating in the recording test were randomly selected out of 80 students who were chosen to do the questionnaire before. They were in three English classes 14A, 14B and 14C, five people in each class. During the recording process, the participants performed in a quiet space. The researcher proceeded to record and archive the recordings with the names and classes of the performers. Moreover, the researcher also received help from colleague Barry who comes from the UK. Barry is a native communication teacher at Ames English Center. As a native teacher, he has enough knowledge and experience to make an objective assessment of a sound recording. He correctly and thoroughly checked the students' recordings and found their errors. As a result, the research results were more accurate and convincing.

\subsection{Procedures}

The study lasted about 12 weeks and was divided into three steps as listed in the following table: 


\begin{tabular}{|l|l|}
\hline \hline \multicolumn{1}{|c|}{ Duration (12 weeks) } & \multicolumn{1}{c|}{ Activities } \\
\hline From the 1st to 6th week & $\begin{array}{l}\text { - Determining the research topic. } \\
\text { - Writing the outline. } \\
\text { - Finding document for completing chapter 2 -Literature review. }\end{array}$ \\
\hline From the 6th to 8th week & $\begin{array}{l}\text { - Designing the questionnaire and recording test. } \\
\text { - Delivering the questionnaire and the recording test. }\end{array}$ \\
\hline From the 8th to 12th week & $\begin{array}{l}\text { - Analyzing the collected data. } \\
\text { - Completing the research. }\end{array}$ \\
\hline
\end{tabular}

\section{Chapter 4: Results and Discussion}

Chapter 4 indicates the results of the study based on the data collected from the questionnaire and the recording test. The findings show the statistical evidence that reveals students' common errors in pronouncing dental consonants. Then, the discussion will follow to wrap up this chapter.

\subsection{Results}

In this section, the researcher gives the full results of the research paper. Final conclusions are drawn from the analysis of data collected from the 80 participants. The analysis results are based on the results of the questionnaire and the recording test that the researcher had previously performed.

\subsubsection{Results from questionnaires}

The researcher received valuable information from 80 respondents who answered the questionnaire. The result has been divided into two main parts including the students' background, their opinion related to pronunciation and the students' common errors in dental sounds with the affecting factors.

\section{Part 1}

\subsubsection{Students' background}

In part 1 of the questionnaire, seven questions were given for preliminary investigation of students. The results show that $100 \%$ of students have learned pronunciation with two phonology modules and they have a length of 7 to 13 years learning English. This part shows that in the process of learning English they have to perform many different tasks besides pronunciation as well as learning about dental sounds.

\section{a. Important factors in speaking students take interest}

The second question was to show the important factors that students take an interest in speaking English, including five crucial elements: grammar, pronunciation, vocabulary, intonation and students' other choices. 
Figure 5: Important factors in speaking students take interest

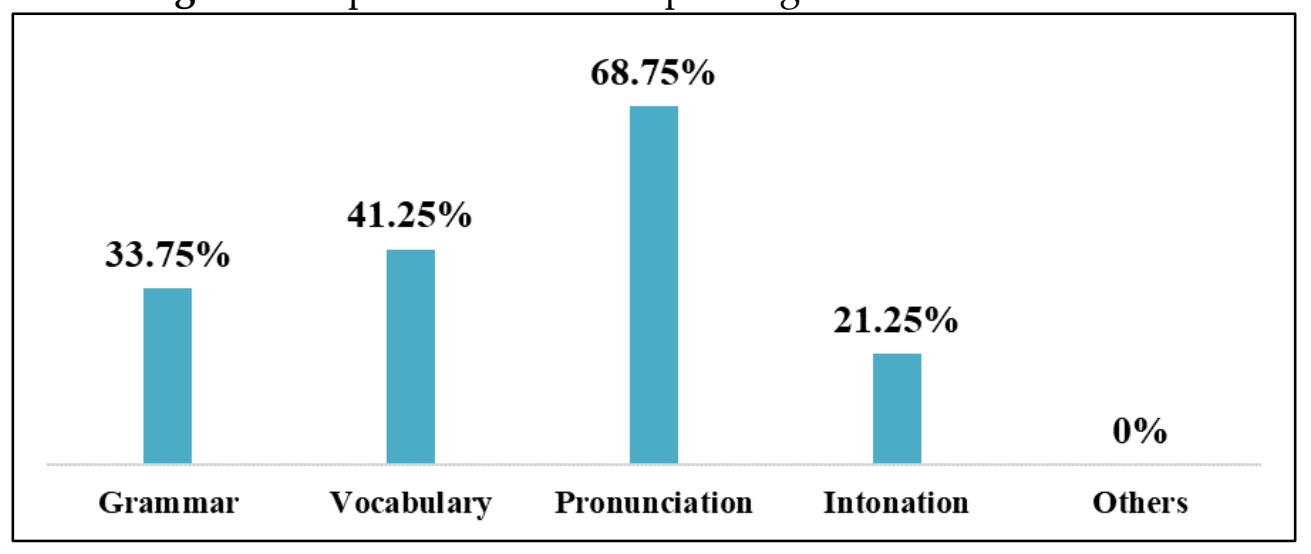

In this question, a student can choose from many appropriate answers (already available) or give their own opinion. From figure 5, it can be seen that more than half percent of students choose pronunciation and vocabulary as the two important factors in speaking skills with $68.75 \%$ of pronunciation and $41.25 \%$ of vocabulary respectively. However, it can be seen that pronunciation accounts for the highest percentage with $68.75 \%$ of people voting as the most important factor. In contrast, other elements such as grammar, vocabulary and intonation received fewer votes and the proportions were $33.75 \%, 41.75 \%$ and $21.25 \%$ respectively. In addition, in the personal comments, the participants did not share any additional comments. As such, most sophomores believe that pronunciation is an important factor in speaking skills.

\section{b. The role of pronunciation}

Figure 6: The role of pronunciation

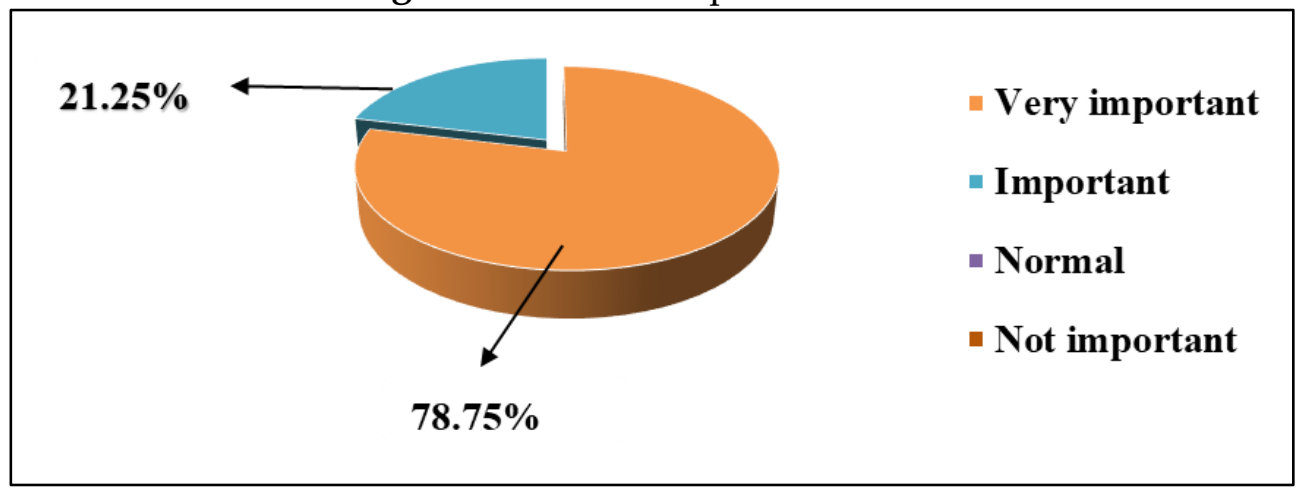

Figure 6 showed that the percentage of students agreeing with the importance of pronunciation in speaking reached $100 \%$. Specifically, 63 out of 80 students admitted that pronunciation is very important, accounting for $78.75 \%$. The remaining 17 students also agreed with the point that pronunciation is important, accounting for $21.25 \%$. Overall, this question once again affirms that the role of pronunciation for students majoring in English is very important. 


\section{c. The frequency of making pronouncing mistakes}

Figure 7: The frequency of making pronouncing mistakes

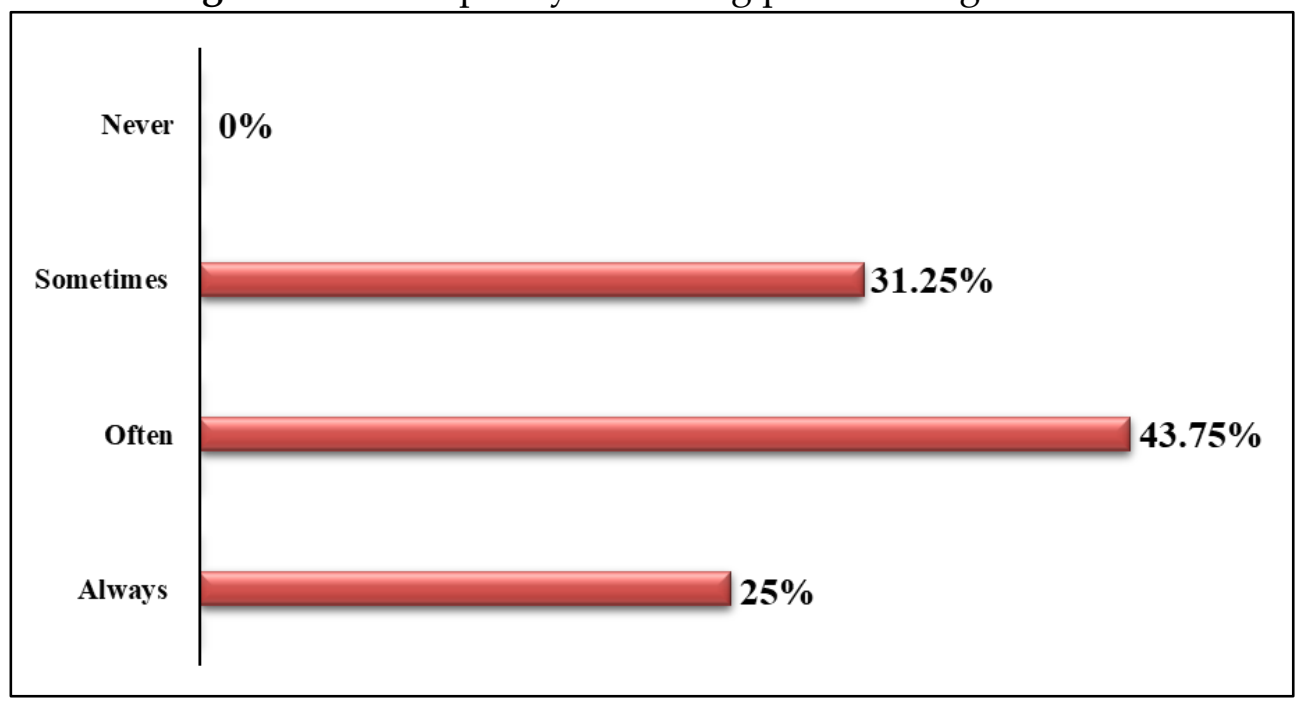

After students were surveyed about the frequency of mispronouncing, more than half of the participants admitted that their pronunciation was often flawed. Specifically, there were 20 students who said that they always pronounce them incorrectly, accounting for $25 \%$. Similarly, 35 other students also said that their pronunciation also made mistakes, accounting for $43.75 \%$. The rest of the students said that the frequency of mispronouncing was only occasionally with 25 students, accounting for $31.25 \%$. Furthermore, there is no student who is confident in their pronunciation with the proof that no student chose the frequency of 'never'. In all in, the number above proved that many English sophomores were facing to pronouncing barrier (Figure 7).

\section{d. Students' self-assessment on pronunciation skill}

Figure 8: Students' self-assessment on pronunciation skill

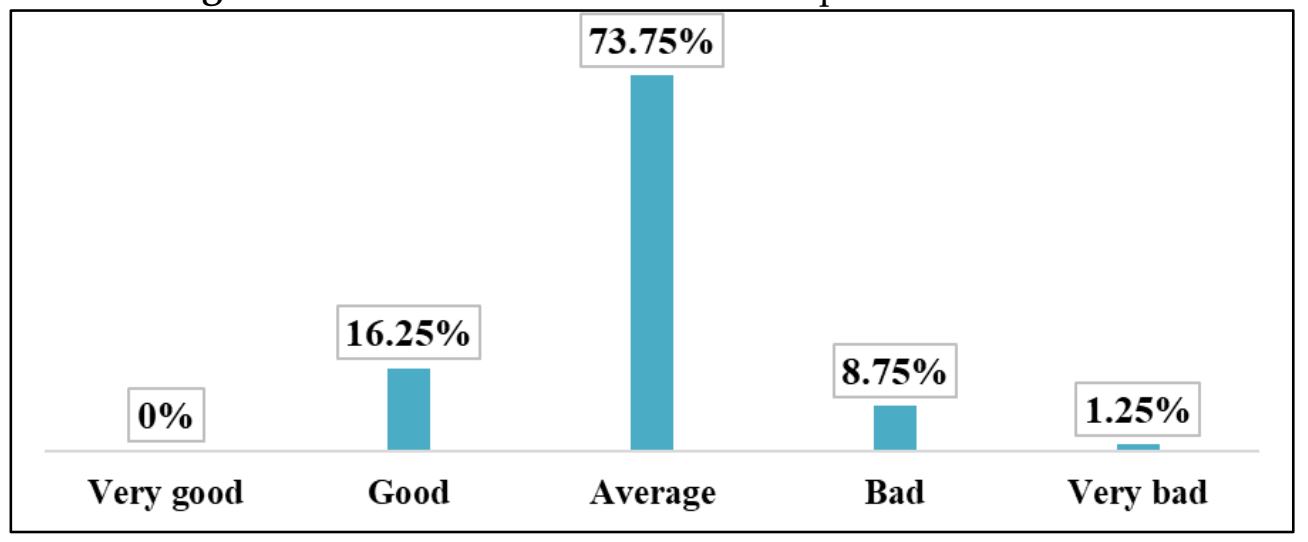

In this figure, it was not difficult to realize that the percentage of students with pronunciation skills at the "average" level was the highest at $73.75 \% \quad$ (59/80). With 
$16.25 \%$ i.e. 13 students out of 80 students they were confident their pronunciation was good. Besides, up to $10 \%(8.75 \%$ bad and $1.25 \%$ very bad) of students admitted that they were bad in pronunciation. More surprisingly, no student found their pronunciation skills very well. Overall, the percentage of students with good and average pronunciation is quite high with a total of $90 \%(72 / 80)$ which proves that students are gradually improving their pronunciation skills.

\section{e. Errors in pronunciation}

Figure 9: Some common errors in pronunciation

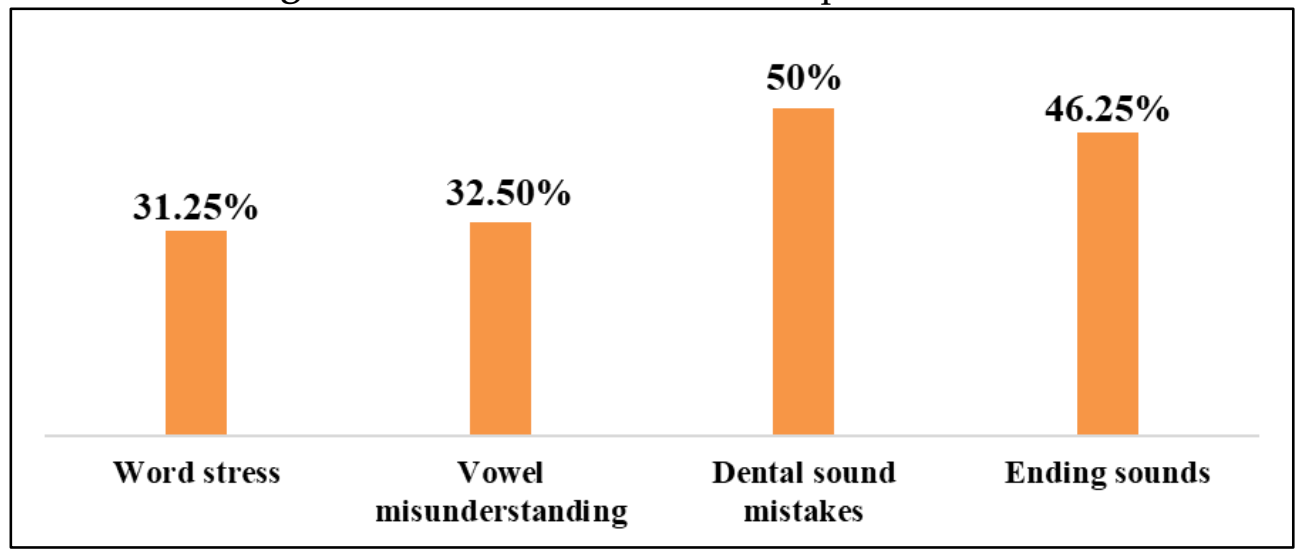

In the question about pronunciation errors, the researcher gave four errors that students often encounter such as word stress, vowel misunderstanding, dental sound mistakes and ending sound. After data processing, it can be seen that $50 \%$ of students were having trouble with dental sounds while speaking English. In addition, the error of the ending sound also accounts for quite a high rate with $47 \%$ of students (37/40). Thus, dental and ending sounds, were greatly important and affected the pronunciation capacity, especially dental sounds, accounting for $50 \%$. In addition, error word stress also needs to be noticed because up to 25 participants are also having trouble with it, accounting for $32.5 \%$. Next is error vowel misunderstanding also needs to be improved, accounting for $31.5 \%$. In addition, the participants did not report any more of the errors they encountered other than those reported by the researcher. In short, dental sounds are an error that learners usually make in their English speaking process.

Based on the data from the questionnaire, the researcher also added questions about how the participants performed to improve their pronunciation. After referencing the research's suggestions, the participants voted at the following rates listening to music $(90 \%)$, watching movies $(83.75 \%)$, talking with friends $(41.25 \%)$ and joining clubs $(26.25 \%)$. This shows that students have different ways they can improve their pronunciation skills. 


\section{Part 2}

From Table 2, it was not difficult to predict that 100\% (80/80) of the participants agreed with the statement one. Specifically, 56 participants strongly agreed with the statement made by the researcher, accounting for $70 \%$ and 24 people agreed, accounting for $30 \%$. There was no one who showed hesitation or objection toward this statement. Therefore, it can be said that students are interested in the importance of pronunciation.

Table 2: Students' awareness toward pronunciation and its importance

\begin{tabular}{|l|c|c|c|c|c|}
\hline Statements & $\begin{array}{c}\text { Strongly } \\
\text { agree } \\
\mathbf{( 5 )}\end{array}$ & $\begin{array}{c}\text { Agree } \\
\mathbf{( 4 )}\end{array}$ & $\begin{array}{c}\text { Neutral } \\
\mathbf{( 3 )}\end{array}$ & $\begin{array}{c}\text { Disagree } \\
\text { (2) }\end{array}$ & $\begin{array}{c}\text { Strongly } \\
\text { disagree } \\
\text { (1) }\end{array}$ \\
\hline $\begin{array}{l}\text { 1. Pronunciation is one of } \\
\text { important factors in learning } \\
\text { English. }\end{array}$ & $70 \%$ & $30 \%$ & $0 \%$ & $0 \%$ & $0 \%$ \\
\hline $\begin{array}{l}\text { 2. You focus on learning other } \\
\text { skills (listening, writing, } \\
\text { reading and speaking) } \\
\text { instead of pronunciation. }\end{array}$ & $37.5 \%$ & $43.75 \%$ & $10.75 \%$ & $2.5 \%$ & $5.5 \%$ \\
\hline
\end{tabular}

However, in statement 2, there were 38 participants who said that they focused on four skills (listening, speaking, reading, writing) rather than learning pronunciation, accounting for $37,5 \%$. In addition, 18 students expressed a neutral opinion, accounting for $43.75 \%$ and the remaining nine students disagreed and showed a positive attitude to pronunciation skills. In general, most students are not aware of the important role of pronunciation.

\subsubsection{The common errors of pronouncing dental sounds and influencing factors}

Table 3: The effect of two different language cultures

\begin{tabular}{|l|c|c|c|c|c|}
\hline Statements & $\begin{array}{c}\text { Strongly } \\
\text { agree } \\
\text { (5) }\end{array}$ & $\begin{array}{c}\text { Agree } \\
\text { (4) }\end{array}$ & $\begin{array}{c}\text { Neutral } \\
\text { (3) }\end{array}$ & $\begin{array}{c}\text { Disagree } \\
\text { (2) }\end{array}$ & $\begin{array}{c}\text { Strongly } \\
\text { disagree } \\
\text { (1) }\end{array}$ \\
\hline $\begin{array}{l}\text { 3. You feel pronunciation difficult } \\
\text { because the language is different } \\
\text { from your mother language. }\end{array}$ & $12.5 \%$ & $51.25 \%$ & $22.5 \%$ & $13.75 \%$ & $0 \%$ \\
\hline $\begin{array}{l}\text { 4. You feel difficult to pronounce } \\
\text { the dental sounds } / / \mathrm{f} /, / \mathrm{v} /, / \theta /, / \delta /) \\
\text { because Vietnamese people do not } \\
\text { have to pronounce them. }\end{array}$ & $20 \%$ & $42.5 \%$ & $23.75 \%$ & $13.75 \%$ & $0 \%$ \\
\hline
\end{tabular}

Sưa : 3. Pronunciation is difficult because the language is different from your mother language. 4 . It is difficult to pronounce the dental sounds ... because ...

In statement 3 issued by the researcher, the participants approved at a high rate. Specifically, there were 10 strongly agreed (accounting for 12.5\%) and 41 participants agreed (accounting for $51.25 \%$ ) with the above statement. Thus, the total number of 
people who agree with this statement is more than half percent of the participants (51/80), accounting for $63.75 \%$. In addition, only 11 participants $(13.75 \%)$ said that their mother language did not have much influence on English pronunciation and no one expressed strong opposition to this statement.

To clarify the difference between Vietnamese and English, the 4th statement was made. Surprisingly, there were $62.5 \%$ of participants agree (strongly agree $20 \%$ and agree $42.5 \%$ ) with difficult pronunciation claims due to the fact that pronunciation is not used by Vietnamese when speaking. In addition to the above comments, 11/80 participants said that their mother language did not affect pronunciation much. In short, most participants have difficulty with pronunciation because they are influenced by their mother language (Vietnamese).

Table 4: The influencing factors of psychology on pronunciation

\begin{tabular}{|l|c|c|c|c|c|}
\hline Statements & $\begin{array}{c}\text { Strongly } \\
\text { agree } \\
\mathbf{( 5 )}\end{array}$ & $\begin{array}{c}\text { Agree } \\
\mathbf{( 4 )}\end{array}$ & $\begin{array}{c}\text { Neutral } \\
\mathbf{( 3 )}\end{array}$ & $\begin{array}{c}\text { Disagree } \\
\text { (2) }\end{array}$ & $\begin{array}{c}\text { Strongly } \\
\text { disagree } \\
\text { (1) }\end{array}$ \\
\hline $\begin{array}{l}\text { 5. You feel bored and } \\
\text { unmotivated to learn } \\
\text { pronunciation. }\end{array}$ & $3.75 \%$ & $21.25 \%$ & $28.75 \%$ & $35 \%$ & $11.25 \%$ \\
\hline $\begin{array}{l}\text { 6. You are not confident when } \\
\text { you pronounce words with } \\
\text { dental sounds. }\end{array}$ & $15 \%$ & $50 \%$ & $25 \%$ & $10 \%$ & $0 \%$ \\
\hline
\end{tabular}

Researchers have come up with statements regarding how psychological factors influence pronunciation. From table 4, it can be seen that psychology influenced the participants' pronunciation with 25\% (20/80). In addition, 37 people claimed that psychology did not affect their pronunciation much, accounting for $46.25 \%$. Thus, although there was not much consent from the participants, it is clear that psychology still influences pronunciation.

However, in the next statement, it is surprising that up to $65 \%$ of participants were not confident with the pronunciation. Specifically, there were 65\% (52/80) participants agreed (strongly agree 15\% and agree 50\%) with this statement. Additionally, 10\% of participants were confidence with their pronunciation and the remaining $25 \%$ gave a neutral opinion. As such, this proves that the participants' pronunciation in confident stems from the fact that they are having trouble with their pronouncing dental sound. 


\begin{tabular}{|l|c|c|c|c|c|}
\hline \multicolumn{7}{c}{ Table 5: The objective influencing factors of imprecise pronunciation } \\
\hline Statements & $\begin{array}{c}\text { Strongly } \\
\text { agree } \\
\text { (5) }\end{array}$ & $\begin{array}{c}\text { Agree } \\
\mathbf{( 4 )}\end{array}$ & $\begin{array}{c}\text { Neutral } \\
\mathbf{( 3 )}\end{array}$ & $\begin{array}{c}\text { Disagree } \\
\text { (2) }\end{array}$ & $\begin{array}{c}\text { Strongly } \\
\text { disagree } \\
\text { (1) }\end{array}$ \\
\hline $\begin{array}{l}\text { 7. Teachers do not have enough } \\
\text { time in class to fix dental sound } \\
\text { mistakes word-by-word for one- } \\
\text { by-one student. }\end{array}$ & $10 \%$ & $46.25 \%$ & $27.5 \%$ & $15 \%$ & $1.25 \%$ \\
\hline $\begin{array}{l}\text { 8. You just have a little time to } \\
\text { practice and there are not many } \\
\text { opportunities for practice with } \\
\text { native speakers. }\end{array}$ & $17.5 \%$ & $47.5 \%$ & $25 \%$ & $10 \%$ & $0 \%$ \\
\hline $\begin{array}{l}\text { 9. The current pronunciation } \\
\text { learning program is not really } \\
\text { effective for students. }\end{array}$ & $6.25 \%$ & $31.25 \%$ & $37.5 \%$ & $25 \%$ & $0 \%$ \\
\hline
\end{tabular}

In the next statements in the questionnaire, it can be seen that the objective factors also related to the students' incorrect pronunciation.

In statement 7,56.25\% of students said teachers did not have enough time in class to fix pronouncing dental sound errors word-by-word for one-by-one. Specifically, $10 \%$ of students strongly agree (8/80) and $46.25 \%$ of students agree (37/80) with the above statement. In addition to the neutral opinions (accounting for 27.5\%), 13 students expressed their disapproval of the statement.

In statement 8 , up to $65 \%$ (with $17.5 \%$ strongly agree and $47.5 \%$ strongly agree) students (52/80) admitted that they did not have enough time to practice pronunciation as well as did not have many opportunities to exchange with native speakers. In addition, $25 \%$ of the respondents were neutral and $10 \%$ thought that they had enough time and opportunity to practice pronunciation.

In the final statement in Table 5, participants expressed concern about the current curriculum because it was not yet suitable for students. Specifically, $30(37.5 \%)$ of the students out of 80 participating students agreed with the statement made by the researcher. 20 students (25\%) said they were suitable with the current study program and the remaining 30 students (37.5\%) had neutral opinions.

As a result of these three statements, it was easily visible that factors such as lack of time, having very few chances to practice and having less opportunity to fix mistakes had a negative impact on improving pronunciation skills. Besides, it also showed the result that the pronunciation program had gradually developed better. 
Table 6: Common errors related to the dental sounds /f/ and /v/

\begin{tabular}{|l|c|c|c|c|c|}
\hline Statements & $\begin{array}{c}\text { Strongly } \\
\text { agree } \\
\text { (5) }\end{array}$ & $\begin{array}{c}\text { Agree } \\
\mathbf{( 4 )}\end{array}$ & $\begin{array}{c}\text { Neutral } \\
\mathbf{( 3 )}\end{array}$ & $\begin{array}{c}\text { Disagree } \\
\text { (2) }\end{array}$ & $\begin{array}{c}\text { Strongly } \\
\text { disagree } \\
\text { (1) }\end{array}$ \\
\hline $\begin{array}{l}\text { 10. You usually pronounce /f/ } \\
\text { and /v/ the same. }\end{array}$ & $15 \%$ & $26.25 \%$ & $25 \%$ & $22.5 \%$ & $11.25 \%$ \\
\hline $\begin{array}{l}\text { 11. You often do not pronounce } \\
\text { /f/ and / / when they are in the } \\
\text { first consonant position. }\end{array}$ & $3.75 \%$ & $37.5 \%$ & $31.25 \%$ & $21.25 \%$ & $6.25 \%$ \\
\hline $\begin{array}{l}\text { 12. You do not realize that 'gh' is } \\
\text { /f/. }\end{array}$ & $11.25 \%$ & $33.75 \%$ & $33.75 \%$ & $18.75 \%$ & $2.5 \%$ \\
\hline
\end{tabular}

In the statements in Table 6, the researchers made statements regarding the errors in students' pronunciation and pointed out specific data to demonstrate each of the claims. Specifically, in statement $10,41.25 \%$ of students agreed with the statement that they pronounce / f / and / v / the same. In detail, there were 15\% strongly agree and $26.25 \%$ agree with the above statement. In addition, those who gave neutral opinions (25\%), the rest of the students said that they pronounced / $\mathrm{f} /$ and / $\mathrm{v} /$ clearly and they did not agree with the above statement (accounting for 33.75\%).

Continuing with statement 11, the percentage of participants giving their opinions was still the same, not too much on the percentage deviation. However, the number of participants who agreed with the point of view is that they usually do not pronounce / $\mathrm{f}$ / and / v / in first position. Specifically, 33 (41.25\%) of the participants agreed (3.75\% strongly agree and $37.5 \%$ agree) with the statement. In addition, there were comments that they pronounced well when / f / and / v / took first position (28.5\%) and 31.25\% were neutral.

In the final statement in table 6, it was surprising that nearly half percent of participants agreed with the researcher's statement. Exactly, nine students strongly agree with the statement that they do not recognize that 'gh' is / $\mathrm{f} /(11.25 \%)$ and 27 people agree with this statement $(33.75 \%)$. In particular, the number of participants who disagreed in this statement was only a small (with $18.75 \%$ disagree and $2.5 \%$ strongly disagree).

In summary, from the results of the above three statements, it can be seen that students are making dental sound mistakes with the typical errors outlined in table 6 (pronouncing /f/ and /v/ the same, do not pronounce /f/ and /v/ when they are in the first consonant position, do not realize that ' $\mathrm{gh}$ ' is /f//).

Table 7: Common errors related to the dental sounds / $\theta /$ and /ð/

\begin{tabular}{|l|c|c|c|c|c|}
\hline Statements & $\begin{array}{c}\text { Strongly } \\
\text { agree } \\
\text { (5) }\end{array}$ & $\begin{array}{c}\text { Agree } \\
\mathbf{( 4 )}\end{array}$ & $\begin{array}{c}\text { Neutral } \\
\mathbf{( 3 )}\end{array}$ & $\begin{array}{c}\text { Disagree } \\
\text { (2) }\end{array}$ & $\begin{array}{c}\text { Strongly } \\
\text { disagree } \\
\text { (1) }\end{array}$ \\
\hline $\begin{array}{l}\text { 13. You will pronounce th } \\
\text { (Vietnamese) instead of / } / .\end{array}$ & $12.5 \%$ & $42.5 \%$ & $20 \%$ & $18.75 \%$ & $6.25 \%$ \\
\hline $\begin{array}{l}\text { 14. You often pronounce 'd' instead } \\
\text { of /ठ/ because it is similar to 'd' in } \\
\text { Vietnamese. }\end{array}$ & $15 \%$ & $42.5 \%$ & $20 \%$ & $18.75 \%$ & $3.75 \%$ \\
\hline
\end{tabular}


15. You often get confused with $/ \theta /$ and /ð/ sounds because they can stand in many positions (beginning, middle, and ending).

\section{$20 \%$}

\begin{tabular}{|c|c|c|c|}
\hline $47.5 \%$ & $20 \%$ & $12.5 \%$ & $0 \%$ \\
\hline
\end{tabular}

Continuing the pronunciation errors associated with dental sounds, many statements were made to collect data.

In Table 7, the first statement brought a surprising number with more than $50 \%$ of participants pronouncing $/ \theta /$ as th. The detailed percentage was as follows: 44 students agreed with the statement (accounting for 55\%). In addition, $18.75 \%$ of people thought their pronunciation was correct and they disagreed with this statement. In addition, 20\% gave their neutral opinions.

In the second statement, the participants frankly faced that they were mispronouncing the following concrete evidence that $57.5 \%$ of participants agreed with the statement (15\% strongly agree and $42.5 \%$ agree). In addition, the rest of the participants thought they were pronouncing correctly (18.75\% disagree and $3.75 \%$ strongly disagree) and $20 \%$ neutral opinion on the statement.

The final statement revealed that the student was having trouble getting the position of the sound in words. Specifically, $67.5 \%$ of students were confused with the statement given by the researcher (with $20 \%$ strongly agree and $47.5 \%$ agree). More surprisingly, in this statement, only 10 people disagreed (accounting for 12.5\%) and no one strongly disagreed.

Overall, the percentages indicated that the students were making mistakes in pronunciation. Specifically, learners are gradually improving their pronunciation through different methods.

Table 8: Some problems related to the dental sounds (/f/, /v/, / $/$ / and /ð/)

\begin{tabular}{|l|c|c|c|c|c|}
\hline Statements & $\begin{array}{c}\text { Strongly } \\
\text { agree } \\
\mathbf{( 5 )}\end{array}$ & $\begin{array}{c}\text { Agree } \\
\mathbf{( 4 )}\end{array}$ & $\begin{array}{c}\text { Neutral } \\
\mathbf{( 3 )}\end{array}$ & $\begin{array}{c}\text { Disagree } \\
\text { (2) }\end{array}$ & $\begin{array}{c}\text { Strongly } \\
\text { disagree } \\
\text { (1) }\end{array}$ \\
\hline $\begin{array}{l}\text { 16. You do not have much } \\
\text { knowledge about dental sounds } \\
/ \mathrm{f} /, / \mathrm{v} /, / \theta /, / \mathrm{\delta} /) .\end{array}$ & $10 \%$ & $45 \%$ & $26.25 \%$ & $16.25 \%$ & $2.5 \%$ \\
\hline $\begin{array}{l}17 . \text { You cannot pronounce dental } \\
\text { sounds } / / \mathrm{f} /, / \mathrm{v} /, / \theta /, / \delta /) \text { well and } \\
\text { often make mistakes when } \\
\text { pronouncing them. }\end{array}$ & $12.5 \%$ & $48.75 \%$ & $28.75 \%$ & $8.75 \%$ & $1.25 \%$ \\
\hline $\begin{array}{l}18 . \text { You have difficulty } \\
\text { distinguishing sounds } / \mathrm{f} / \text { or } / \mathrm{v} / \\
\text { and } / \theta / \text { or } / \delta /) \text { in a sentence. }\end{array}$ & $12.5 \%$ & $58.75 \%$ & $20 \%$ & $8.75 \%$ & $0 \%$ \\
\hline
\end{tabular}

Dental sounds problem such as knowledge, pronunciation and discrimination were also given in the table above.

Specifically, the researcher stated that students did not have much knowledge about dental sounds and received a lot of approval from 44 students, accounting for $55 \%$ 
(10\% strongly agree and $45 \%$ agree). Therefore, the students learned about pronunciation but did not learn in depth about phonology. Besides, 21 students had neutral opinions (26.25\%). However, there were also students who showed understanding of dental sounds through the fact that $16.25 \%$ of the students disagreed and $2.5 \%$ strongly disagreed with the statement above.

In the next statement, the students frankly admitted their pronunciation was not good, as evidenced by $61.25 \%$ of students agreed (12.5\% strongly agree and $48.75 \%$ agree) with this statement. In addition, some students who have good pronunciation have expressed disagreement $(8.75 \%$ disagree and $1.25 \%$ strongly disagree). There were $28.75 \%$ of students in the group of neutral opinion.

In the final statement of this table, the students showed that they were having difficulty separating the syllables (/f/ or /v/ and / $\theta /$ or $/ ð /)$. Specifically, 57/80 students agreed with the above idea, accounting for $71.25 \%$ (12.5\% strongly agree and $58.75 \%$ agree). In this statement, there was no strong objection. Only $8.75 \%$ of the students expressed disagreement.

Thus, students are making mistakes about dental sounds which also affect their pronunciation.

Table 9: The objective influencing factors of verbal gestures

\begin{tabular}{|l|c|c|c|c|c|}
\hline Statements & $\begin{array}{c}\text { Strongly } \\
\text { agree } \\
\text { (5) }\end{array}$ & $\begin{array}{c}\text { Agree } \\
\mathbf{( 4 )}\end{array}$ & $\begin{array}{c}\text { Neutral } \\
\text { (3) }\end{array}$ & $\begin{array}{c}\text { Disagree } \\
\text { (2) }\end{array}$ & $\begin{array}{c}\text { Strongly } \\
\text { disagree } \\
\text { (1) }\end{array}$ \\
\hline $\begin{array}{l}\text { 19. You have to combine many } \\
\text { parts (lip, teeth, tongue, when } \\
\text { pronouncing dental sounds to } \\
\text { make you have trouble. }\end{array}$ & $18.75 \%$ & $58.75 \%$ & $12.5 \%$ & $10 \%$ & $0 \%$ \\
\hline $\begin{array}{l}\text { 20. You often get the wrong } \\
\text { position of the vocalization parts. }\end{array}$ & $20 \%$ & $48.75 \%$ & $22.5 \%$ & $6.25 \%$ & $2.5 \%$ \\
\hline
\end{tabular}

In the last two statements in the questionnaire, the researcher focuses on the verbal gestures. Obviously, the combination of articulating parts was causing difficulties for students with a very high approval rate of $77.5 \%$ (62/80). Specifically, $18.75 \%$ of students strongly agreed with the statement and 58.75\% agreed. In addition, 10 students gave a neutral opinion and $10 \%$ of the students were confident that they were making good combinations of syllables.

Continuing with the last statement, the researcher made more observations about the wrong sound is pronounced due to the wrong syllable position. This statement received the majority of the students with $68.75 \%$ (20\% strongly agree and $48.75 \%$ agree). In particular, more and more about the final statements, the students strongly faced the problem of their own pronunciation with $8.75 \%$ expressed disapproval.

From the analysis results, it shows that the syllable positions are somewhat to the pronunciation of the sounds. Specifically, students are making the wrong combinations 
of position as well as using multiple pronunciation parts at the same time making it difficult for them.

\subsubsection{Results from recording tests}

In order to correctly collect errors in dental sounds, the researcher conducted a recording test with 15 randomly selected students. Through the test, the collected data will help the researcher clarify the errors in the dental sounds $(/ \mathrm{f} /, / \mathrm{v} /, / \theta /, /$ ð/).

The recording test is designed with 10 pairs of dental sounds $(/ \mathrm{f} /, / \mathrm{v} /, / \theta /, / ð /)$ and six simple sentences containing the dental sounds. In the sound pair section, students will slowly pronounce each sound pair available. After pronouncing the pairs of sounds, students pronounce the single sentences to increase the difficulty. Students pronounce in a natural, loud and fluent tone.

The entire process was done in a quiet space, and the recording is clear and unaffected by background noise. After saving the entire recording, the researcher listened to the recording again and analyzed it carefully with the assistance of a local colleague and instructor. Through the recording, the researcher discovered many errors that the students were facing and came up with the results of the analysis that was performed on the side.

\subsubsection{Errors of dental sounds / $f /$ and /v/}

\section{a. Errors in pronouncing single word}

Vine - Fine

Vote - Photo

Over - Orphan

Love - Laugh

Leave - Leaf

Figure 10: Errors in pronouncing word by word

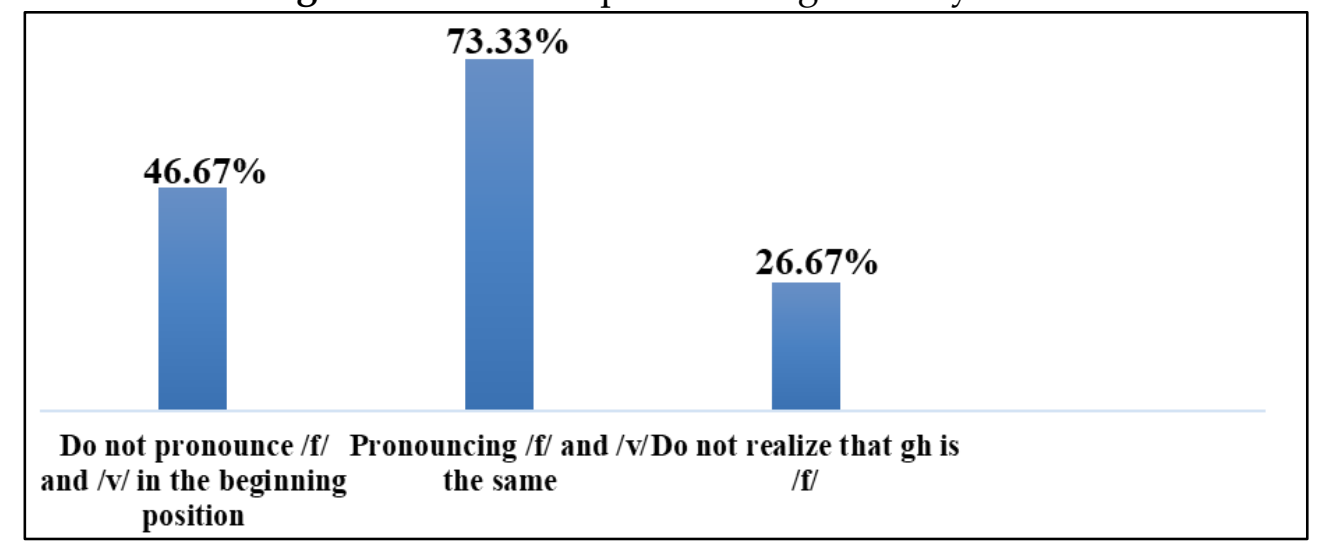


From Figure 10, it can be seen that the participants are making mistakes in the pronunciation of word by word. Specifically, $46.67 \%$ did not pronounce / $/$ and /f/ when they were in the beginning consonant position $73.33 \%$ of participants pronounced /f/ and $/ \mathrm{v} /$ the same and $26.67 \%$ did not realize that $g h$ is $/ f /$. In the first error (did not pronounce $/ \mathrm{v} /$ and /f/ when they were in the beginning consonant position), the researcher gave two negative pairs with a specific suggestion by underlining the letter containing the dental sound (vine, fine, vote, photo). The participants, even though they received the hint, emphasized the last consonant over the beginning position containing the dental sounds. More surprisingly, the proportion of participants pronounced /f/ and /v/ the same were more than half a percent higher. They have not yet shown the difference between / v / and / f / by pronouncing words like love, leave and leaf. Finally, in this error, $26.67 \%$ of people did not realize that gh (laugh) is /f/ and they pronounced /f/ to / $/$ / They are careless in their pronunciation even though the researcher has suggested that gh is pronounced / $\mathrm{f} /$ in English.

\section{b. Errors in pronouncing in sentence}

- He ate the fish and half a loaf of bread, then he left.

- Val survived the five hour drive.

- My life is tough, but I laugh.

Figure 11: Errors in pronouncing in sentence

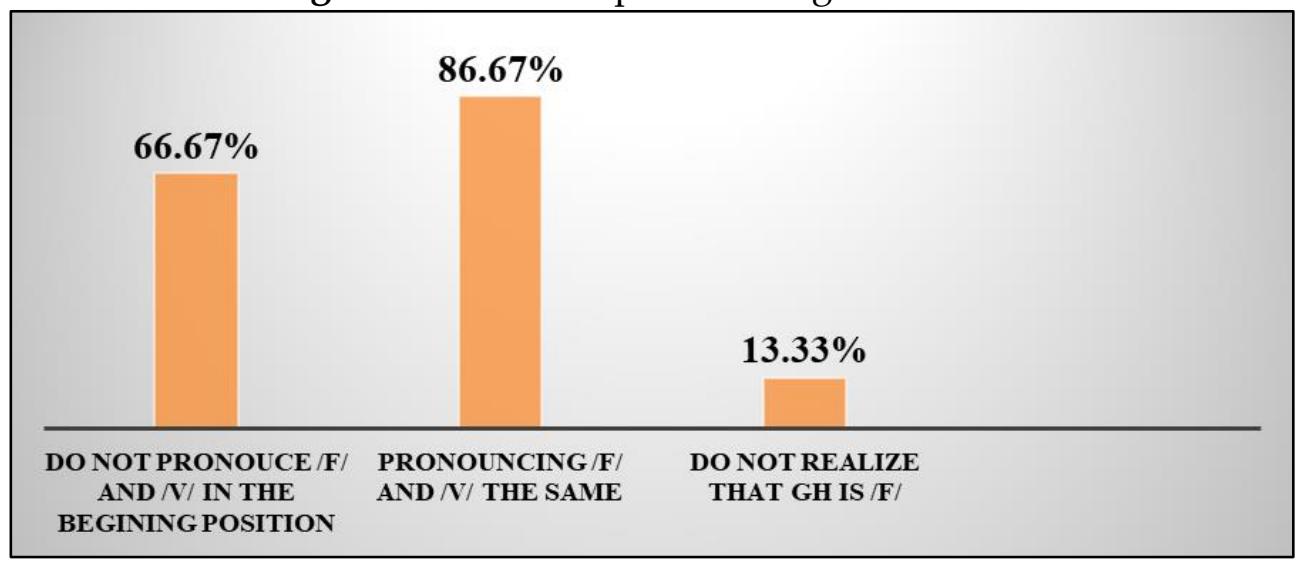

In this section, the researcher gave three simple sentences with dental sounds in words. Surprisingly, none of the participants correctly pronounced the three sentences correctly. It was demonstrated by the proportion of people who pronounced / $\mathrm{f} / \mathrm{and} / \mathrm{v} /$ were similar, accounting for $86.67 \%$ by pronouncing the words as fish, five, drive, survived, laugh, left. In addition, the participants focused on the ending sounds but ignored the first tones, proving that $66.67 \%$ of participants made mistakes. However, the failure to recognize $g h$ (tough, laugh) as / f / in this section has made good progress (13.33\%). Only 2 participants still make mistakes in this part.

In general, students did not pay attention to the difference between /f / and /v / in dental sounds. Due to their habit of focusing on the last sound, they had errors in the 
pronunciation of the first position. The results also proved that the participants were making their pronouncing dental sounds mistakes.

\subsubsection{Errors of dental sounds $/ \theta /$ and /ð/}

\section{a. Errors in pronouncing word by word}

Thing - $\underline{\text { This }}$

Three - There

Method - Mother

Mouth - With

Truth - Bathe

Figure 12: Errors in pronouncing word by word

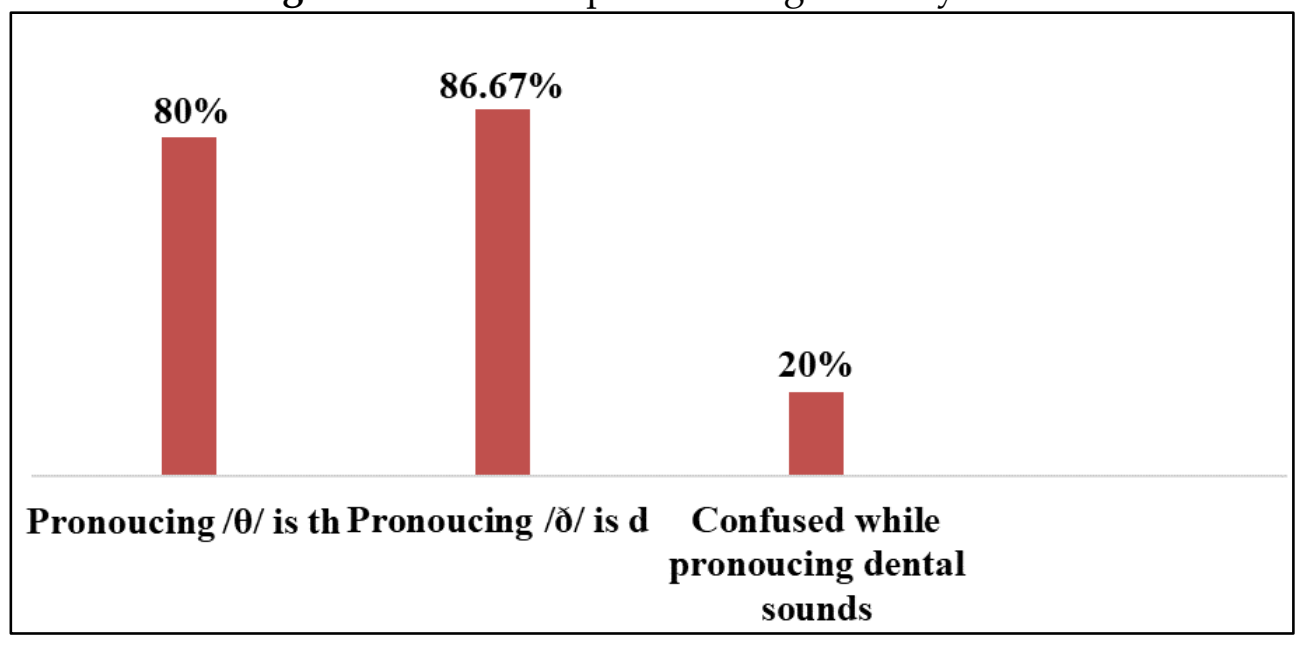

In the recording test $/ \theta /$ and $/ ð /$ participants continue to have trouble when they pronounce it wrong. Participants almost continuously pronounce $/ \theta /$ is 'th' (thing like thinh in Vietnamese), accounting for $80 \%(12 / 15)$. They are influenced by the 'th' sound in their mother language (Vietnamese). The influence of the mother language on the pronunciation of dental sounds continued to meet again. They pronounced /ð/ like' $\mathrm{d}^{\prime}$ (this, there, mother), accounting for $86.67 \%$. Besides, the $/ \theta /$ and $/ ð /$ dental sounds were so diverse in terms of positions in the word (beginning, middle, and ending), which confused participants in their pronunciation. Specifically, there were three participants who were confused when they pronounced dental sounds $(/ \theta /$ and /ð/), accounting for $20 \%$.

In summary, most of the participants had problems with this sound and the main reason stemmed from the influence of their mother language. They pronounce English in the way they pronounce their mother language which makes it difficult for them to discern sounds. 


\section{b. Errors in pronouncing in sentence}

- Kathy is the author of the Math book.

- There are three athletes from North American.

- What are those things over there?

Figure 13: Errors in pronouncing in sentence

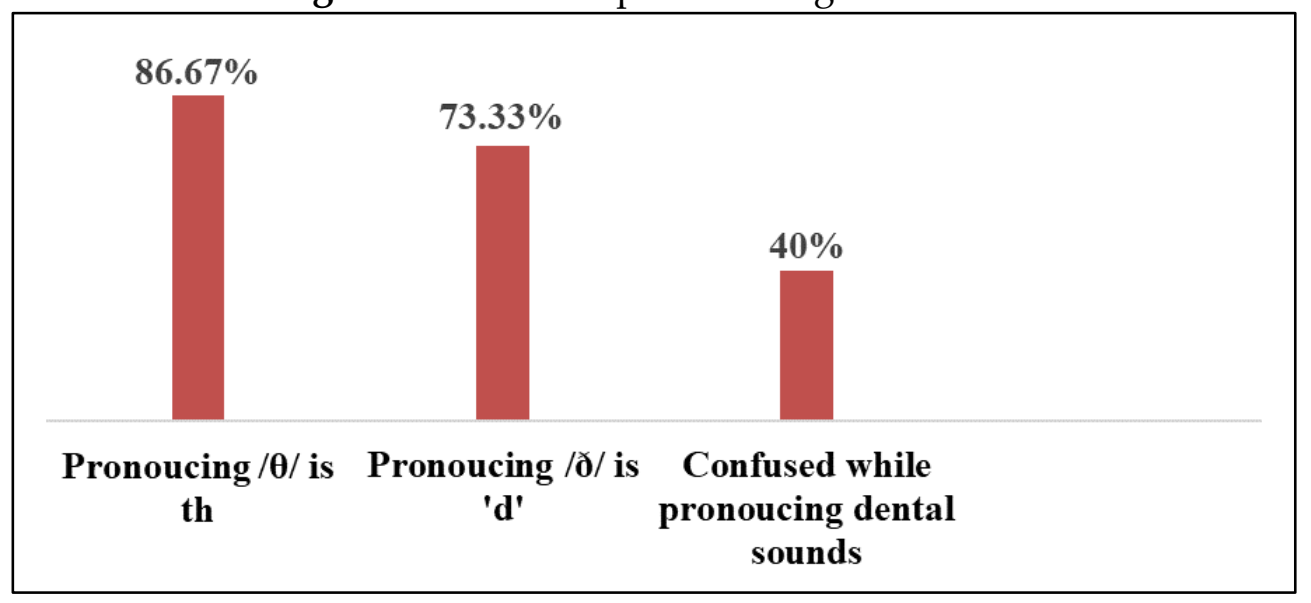

Continuing to check the recording, the researcher noticed more clearly the mistakes students were facing. Specifically, $86.67 \%$ of students pronounced $/ \theta /$ is 'th' in their pronunciation. Students did not realize the difference between $/ \theta /$ and ' $t$ ' (Vietnamese) so they still pronounce the same two sounds. In addition, for sound / $/$, students also encountered this error through their pronunciation of sentences containing /ठ/ (There, three, the, those.). To increase the difficulty for students, in sentence (1) the dental sounds constantly appeared and the confusion of the students was clearly visible in their recordings (6/15), accounting for $40 \%$.

Thus, it can be seen that the mistakes students are making, it were shown more clearly in sentence pronunciation. They were more careful after making mistakes in word pronunciation, but they still repeat mistakes.

\subsection{Discussion}

The purpose of the research was to investigate whether the majored students at Tay Do University would make mistakes in pronouncing the dental sounds so that the researchers looked at common errors in dental consonants of English-majored sophomores and analyzed them to find the causes of these errors. After undergoing the through analysis of the questionnaires and the recording tests, it was apparent that students' principal problems causing imprecise pronunciation in three ending sound pairs $/ \theta /, / \delta /, / f /$ and $/ \mathrm{v} /$. To clarify these errors, the researcher would like to recall them one by one as follows.

First of all, according to the data analysis, although the participants' interest in the importance of pronunciation which is an indispensable part of learning and participating in communication, they reported that they often pay no attention to pronounce the dental 
consonants. Therefore, making mistakes with dental sounds $(/ \theta /, / \mathrm{d} /, / \mathrm{f} /$ and $/ \mathrm{v} /)$ was very popular for English learners. In fact, students did not draw any attention to four these consonants, leading to their incomplete pronunciation. For labio-dental (/f/ and /v/) pair, many students pronounce / $\mathrm{f} /$ and / $\mathrm{v} /$ the same, making the pronunciation incorrect. Especially, when / $\mathrm{f} /$ and / $\mathrm{v} /$ are in the beginning position, they are often removed and students pay more attention to the final consonant. As for inter-dental $(/ \theta /$ and $/ ð /)$, due to the profound influence of the mother language, most students pronounce these sounds similar to Vietnamese $(/ \theta /$ like 'th', $/ ð /$ like ' $d$ '). In addition to the errors already mentioned, the remaining errors are negligible and students are gradually improving them.

Secondly, through the recording test, the students demonstrated that it is not easy to make a tooth sound, although they always receive a suggestion from the researcher during the procedure. Although students did not admit errors in the questionnaire, in the recording they made pronunciation mistakes such as unclear pronunciation and omission. Besides the errors in dental sounds, the researchers also found that more students also had problems with ending consonants. However, students improved their confusion of encountering various consonant positions (beginning, middle, ending).

Thirdly, as can be seen in the questionnaire analyzing section, there are two main factors that caused those pronunciation errors. The first was the subjective influencing factors, the students feel difficult to pronounce the dental sounds because they had to face their negative personal effects such as their mother tongue made them foreign with those sounds, lack of confidence affected directly on their good pronunciation and the underestimating the importance of pronunciation made them encounter many difficulties in communication. However, all those influences could be improved by themselves. The second factor was the objective influence, the participants admitted that the pronunciation time in class were not enough to practice so the lecturers just had a little time to fix ending sound mistakes word-by-word for one-by-one student. Moreover, the second year students rarely had chances to talk with the foreigners or English natives. In summary, the research results show that second year students have many difficulties in pronouncing the dental sounds. This denoted that students paid special attention to other English skills rather than pronunciation, so they could not express precisely their mean for their listeners. Current research results show that the errors of pronouncing the same consonants (f/, /v/ the same) and pronouncing the same mother language $(/ \theta /$ like 'th', /ð/ like 'd') are the two most common mistakes among students. The difficulty of sound position is negligible.

\section{Chapter 5: Conclusions, Implications, Limitations and Recommendations}

This chapter presents (1) the conclusions, (2) implications, (3) limitations and (4) puts forward recommendations for further research. 


\subsection{Conclusions}

After researching the hypotheses, conducting experimental tests, researchers have come up with conclusions. Pronunciation is an incredibly vital task since it inevitably involves two other main skills including listening comprehension and speaking. Certainly, when engaging in communication, the naturalness, clearness and preciseness of pronunciation should be given top priority so that the listeners could receive lit easily and accurately. This research has identified, analyzed and synthesized errors in pronouncing dental sounds in English / $\theta /, / ð / / f /$ and /v/. In the analysis results of the / f / and / v / negative pairs, the most common mistake among students was to pronounce / $\mathrm{f} /$ and / $\mathrm{v} /$ the same and usually not pronounce when / $\mathrm{f} /$ and / $\mathrm{v} /$ in first position. With the / $\mathrm{t} /$ and / $\mathrm{d} /$ pairs substitution was the most common error. For example, students used the habit of speaking their native language to apply English speaking, making the pronunciation not standard. These errors have been proven through reliable ratios that are collected and analyzed in detail. Besides, other factors such as the learning environment and psychology also partly interfered with the students' pronunciation. Moreover, in addition to the common errors in dental sounds, during the analysis of the recording results, the researchers also discovered more about the ending sound errors of the students. Finally, regarding two major influencing factors (subjective and objective elements) led to the difficulties in pronouncing dental consonants, which English major sophomores at Tay Do University had to deal with.

\subsection{Implications}

Dental sounds study $(/ \theta /, / ð /, / \mathrm{v} /$ and $/ \mathrm{f} /)$ was conducted to assist students in identifying existing errors correctly and promptly find a way to solve it effectively. In addition, these errors are not paid much attention to by students because they have little effect on the listener's understanding of the communication process. However, students should also pay attention to avoid the incorrect pronunciation that leads to the wrong meaning of words. Therefore, the researcher conducts research with three main implications. First of all, the students learn that they were making dental sounds mistakes and need to work on them. Secondly, students find out the right methods to practice and study, and find native speakers or teachers to get exact instructions. The best way is learning at home through movies, music or websites. Finally, it is hoped that this study would be helpful for pronunciation teachers to get more insights into their students' problems and therefore make appropriate adjustments to their teaching method.

\subsection{Limitations}

In spite of the fact that carrying out this research was a wonderful experience for the researcher, there remained some inevitable restrictions. Firstly, in view of the time limitation, the researcher could not cover deeply the errors of the other sounds in pronouncing aspect. Secondly, the unenthusiastic cooperation of a few students in the questionnaire led to the results were not accurate utterly, some students only answered the questions perfunctorily. Thirdly, the recording process did not have good quality 
because the speakers read with a fairly low volume. Therefore, all the final consonants are very hard to recognize exactly. The last one was the most difficulty part of this investigation, student and research schedules overlap, making data collection time slow. However, the researchers truly hoped that, in its scope, the current paper would be useful for English majored sophomores at Tay Do University in their pronunciation learning process and for those having a strong interest in English pronunciation.

\subsection{Recommendations}

Based on the limitations mentioned above, the further research should address two following issues. First of all, this research subject ought to expand with a larger scale in order that the research would be more dependable and convincing. Actually, researchers could select not only English majored students, but also students from other majors at Tay Do university or even people in different schools who are about to approach the practice of pronunciation. Secondly, during the progression of the study, the researchers recognized that besides the errors in the above dental sounds, some other ending sounds were also pronounced wrongly. This finding would pave the way for further researchers to develop their pronunciation studies.

\section{Conflicts of Interest Statement}

The authors whose names are listed immediately below certify that they have no conflicts of interest, authorship, and disclosures in publication. They confirm that this work is original and has not been published elsewhere, nor is it currently under consideration for publication elsewhere.

\section{About the authors}

M.A. Thi Truc Ly Bui and M.A. Thanh Hiep Mai graduated from Can Tho University and have 13-year experience of teaching English; currently are senior lecturers at Tay Do University. The article co-author Thao Nguyen Nguyen who also is experienced in teaching English.

\section{References}

\section{a. Books}

Al-Aqlobi, M. O. (2013). Difficulties in pronouncing and perceiving English word final consonant clusters among Saudi ESL learners. Ann Arbor: ProQuest Information and Learning.

Avery, \& Ehrlich (1992). Teaching American English pronunciation. Oxford: University Press.

Cambridge Advanced Learner's Dictionary (Cambridge University Press, 2008 - 1799 pages) 
Celce-Murcia, M., \& Brinton, D. M., \& Goodwin (1996). Teaching pronunciation: A reference for teachers of English to speakers of other languages. Cambridge University Press.

Cook, V. (1996). Second Language Learning and Language Teaching. London: Arnold.

Duong, T. N. (2008). Mistake or Vietnamese English. Ha Noi: Vietnam National University. Moosa, M. H. (1979). Difficulties of Learning the Pronunciation and Structural Differences Between Arabic and English. MA Dissertation, Library of Saudi Arabia, Educational mission; Texas.

Nguyen, V. N. H. (2015) Difficulties in Communication with English Speaking People of English majors juniors at TDU and their solutions.

Paulson, C. B., \& Bruder, M. N. (1976). Teaching English as a second language: Techniques and procedures. Cambridge, MA: Winthrop Publishers, Inc.

Qui, H. N. (2010). English Phonetic and Phonology. Can Tho: Can Tho University.

Richards, C. J. \& Schmidt, R. (2002). Longman dictionary of language teaching and applied linguistics. England: Longman Publishing Group.

Roach, P. (2009). English phonetics and phonology. Cambridge: Cambridge University Press. Seidlhofer, B. (2001). Pronunciation. In R. Carter \& D. Nunan (Eds.), The Cambridge Guide to Teaching English to Speakers of Other Languages (The Cambridge Guides, pp. 56-65).

Kristin Lems, Leah D. Miller, and Tenena M. Soro, (2010). Teaching Reading to English Language Learners.

Wei, Y, \& Zhou, Y. (2002). Insights into English Pronunciation Problems of Thai students.

\section{b. Internet}

Adult Migrant English Program Research Centre, 2002: What is Pronunciation? http://www.nceltr.mq.edu.au/pdamep

A study on common pronunciation mistakes faced by first year English majors at Hai Phong private university- Hang Nguyen (2014)

Definition of pronunciation - Wikipedia. Retrieved from https://en.wikipedia.org/wiki/Pronunciation

Definition of consonants - Cambridge Academic Content Dictionary. Retrieved from https://dictionary.cambridge.org/dictionary/english/consonant

Definition of pronunciation - Oxford Advanced Learner's Dictionary, 8th end (2008). Available:

https://www.oxfordlearnersdictionaries.com/definition/english/pronunciation

Suwartono (2006:41). It is Important to Learn English Pronunciation as a Foreign Language Amelia $\quad$ Widi

Astuti:

Academia.edu/It is Important to Learn English Pronunciation as a Foreign Langua ge

Nguyen Tien Dung Faculty of Foreign Languages, Ba Ria (2014) - Vung Tau University. Nguyen, T. T. T. (2007). Difficulties for Vietnamese when pronouncing English: Final Consonants [Online]. Available: http://www.divaportal.org/smash/record.jsf?pid=diva2\%3A518290\&dswid=9052 
Otlowski, M. (1998). Pronunciation : What Are the Expectations?. In The Internet TESL Journal [online], vol.4, no.1. Available at: http://iteslj.org/Articles/OtlowskiPronunciation.html.

Pronunciation and listening comprehension. Retrieved from: https://www.omniglot.com/language/pronunciation.htm

Students' Difficulties in Pronouncing the English Labiodental Sound (Herman). Retrieved from: http://article.sciencepublishinggroup.com/html/10.11648.j.cls.20160201.11.html

Teaching and Research, Macquarie University, Retrieved from: http://www.ameprc.mq.edu.au/docs/fact sheets/01Pronunciation.pdf

Yates, L. (2002). What is pronunciation? Adult Migrant English Program (AMEP) Research Centre Fact Sheets, Sydney, National Centre for English Language xii Teaching and Research, Macquarie University. 01 Pronunciation A4 (mq.edu.au)

\section{c. Journals}

Akudela Tom (2009). Influence of Mother Tongue Interference in the Learning of English Sounds in Secondary Schools in Afikpo South Local Government Area of Ebonyi State.

Chavangklang, P. (2013). Enhancing final consonant pronunciation skill of the first year students at Nakhonratchasima Rajabhat University through E-learning. Procedia - Social and Behavioral Sciences Journal, 91. Chitravelu, 2005.

Çimenli, B. (2015). On pronunciation teaching and semiotics. Procedia - Social and Behavioral Sciences Journal, 199, 634-640.

Honey P. J. (1987). Vietnamese speakers. In M. Swan \& B. Smith, Learner English: A teacher's guide to interference and other problems. (1 ${ }^{\text {st }}$ ed., pp. 243-248). London: Cambridge University Press.

Integrating Research and Professional Development on Pronunciation Teaching in a National Adult ESL Program Anne Burns Macquarie University, Australia (2006).

Judith A. Breitkreutz, Tracey M. Derwing, and Marian J. Rossiter (2001). Pronunciation Teaching Practices in Canada

James T. (2010). The Significance of Pronunciation in English Language Teaching.

Macdonald, Yule, and Powers (1994). and Dewing, Munro, and Wiebe (1997). Language awareness and second language pronunciation: A classroom study.

Nation, I. S. P., \& Newton, J. (2009). Teaching ESL/EFL listening and speaking. New York: Routledge, Taylor and Francis.

O'Neal, G. (2015). Segmental repair and interactional intelligibility: The relationship between consonant deletion, consonant insertion, and pronunciation intelligibility in English as a Lingua Franca in Japan. Journal of Pragmatics, 85, pp. 122-134.

Rajadurai (2001). Importance of correct pronunciation in spoken English: Dimension of second language learners' perspective.

Shak, P., Chang, S.L. and Stephen, J. (2016). Pronunciation problems: A case study on English pronunciation errors of low proficient students. International Journal of Language Education and Applied Linguistics, 4, 25-35. 
Thi Truc Ly Bui, Thanh Hiep Mai, Thao Nguyen Nguyen

Creative Commons licensing terms

Authors will retain the copyright of their published articles agreeing that a Creative Commons Attribution 4.0 International License (CC BY 4.0) terms will be applied to their work. Under the terms of this license, no permission is required from the author(s) or publisher for members of the community to copy, distribute, transmit or adapt the article content, providing a proper, prominent and unambiguous attribution to the authors in a manner that makes clear that the materials are being reused under permission of a Creative Commons License. Views, opinions, and conclusions expressed in this research article are views, opinions and conclusions of the author(s). Open Access Publishing Group and European Journal of English Language Teaching shall not be responsible or answerable for any loss, damage or liability caused in relation to/arising out of conflict of interests, copyright violations and inappropriate or inaccurate use of any kind content related or integrated on the research work. All the published works are meeting the Open Access Publishing requirements and can be freely accessed, shared, modified, distributed and used in educational, commercial and non-commercial purposes under a Creative Commons Attribution 4.0 International License (CC BY 4.0). 